\title{
EL ARBITRAJE ISLÁMICO EN MATERIA DE MATRIMONIO Y FAMILIA EN EL REINO UNIDO
}

\author{
Irene María BRIONES MARTÍNEZ \\ Acreditada como Catedrática \\ Universidad Complutense de Madrid \\ iremar@der.ucm.es
}

\begin{abstract}
RESUMEN
El modo de extinguirse el matrimonio refleja la concepción que se tiene del mismo, la fiel o errónea visión de la naturaleza bumana, y el modo de construirse las relaciones humanas más fundamentales de la sociedad. Estudiar estas claves en las grandes religiones es suficiente motivo para iniciar un trabajo sobre el imperativo de conciencia que exige extinguir un vínculo conforme al Derecho religioso que libremente se ha elegido como rito para contraer y como compromiso de vida. Los tribunales religiosos, asi las cosas, convirtiéndose en guardianes del matrimonio son guardianes de la fe. Analizaremos el Islam, conociendo cómo se ha ido pergeñando la posibilidad de que los tribunales islámicos puedan tomar decisiones de Derecho privado de un modo no oficial y con los tribunales de arbitraje, aprovechándose de la puesta en vigor de leyes de arbitraje que permiten una resolución alternativa del conflicto en el Reino Unido.
\end{abstract}

Palabras clave: matrimonio, religión, Islam, Sharia, derecho de familia, arbitraje.

\section{ABSTRACT}

The way in which marriage terminates shows its conception as well as the right or wrong vision of human nature and the way most important relationships are built. Studying such key elements in major religions is enough reason to start a piece of work about the imposed awareness needed to break a bond which complies with religious laws and which has been chosen as a ritual and a way of life on a free will basis. Yet, religious courts when they watch over marriage they also watch over faith. We will look into Islam and we will learn about how the possibility for Islamic courts to make private legal judgments on an unofficial basis plotted together with the Courts of Arbitration, taking advantage of the implementation of Arbitration laws which allow an alternative conflict decision in the UK.

Keywords: marriage, religion, Islam, Sharia, family law, arbitration.

\section{ZUSAMMENFASSUNG}

Die Weise, in der die Ehe ausstirbt, gebt überein mit der Auffassung, die man von ihr hat: die getreue oder falsche Sicht auf die Natur des Menschen, und die Weise des Aufbaus der grundlegendsten menschlichen Beziebungen der Gesell- 
schaft. Die Untersuchung dieser Kenngrößen innerbalb der großen Religionen ist Grund genug um eine Arbeit zu schreiben, die dem Gewissen Rechnung trägt, welches fordert, dass man die Verbindung zum religiösen Rechtssystem auslöscht, eine Verbindung, die man frei als Ritual gewählt hat, um der Eheschließung und der Verpflichtung im Leben Audruck zu verleihen. Die religiösen Gerichte, so ist es defacto, verwandeln sich in Wächter über die Ehe während sie doch Wächter des Glaubens sind. Bei der Untersuchung des Islam lernen wir kennen, wie dort die Möglichkeit herausgearbeitet wird, dass die islamischen Gerichte Entscheidungen des Privatrechts treffen, die als nicht ofifiziell gelten. Durch die Schiedsgerichte werden Gesetze für Schiedsgerichtsverfahren gültig verabschiedet, die eine alternative Konfliktlösung in Großbritannien ermöglichen.

Schlüsselwörter: Ehe, Religion, Islam, Sharia, Familienrecht, Schiedsgerichtsverfahren.

SUMARIO: I. INTRODUCCIÓN.-II. EL SISTEMA DE ESTABLISHMENT CHURCH FRENTE AL PLURALISMO LEGAL Y RELIGIOSO.-III. ENFOCANDO EL DEBATE DE LOS TRIBUNALES RELIGIOSOS Y EL PLURALISMO LEGAL COMO EXPRESIÓN DE IDENTIDAD Y DEL PRINCIPIO DE AUTONOMÍA.-1. Autonomía de las confesiones.-2. Cuestiones de conciencia individual y consensuada como parte del derecho a la autonomía.-3. El arbitraje como conciliación entre la autonomía institucional y personal.-IV. SHARIA COUNCILS Y MUSLIM ARBITRATION TRIBUNALS.-1. Procedimiento de los Shariah Councils.-A) Si el divorcio es instado por el varón.-B) Si el divorcio es instado por la mujer.-2. Composición y procedimiento del MAT.-3. Las enmiendas del one law for all en los acuerdos de arbitraje.-A) The Equality Act 2010.B) The Arbitration Act 1996.-C) The Family Law Act 1996.-D) The Criminal Justice and Public Order Act 1994.-E) The Court and Legal Services Act 1990.V. PROPUESTA FINAL: LA ACOMODACIÓN ENTRE EL DERECHO RELIGIOSO Y EL DERECHO SECULAR.-1. Gobernanza religiosa y acomodación.-2. Los desafíos de la acomodación. Hacia una razonable transformación.

\section{INTRODUCCIÓN}

Aun sustentándose Europa occidental sobre el principio de la secularización de los poderes públicos, la religión siempre recobra vitalidad en la sociedad europea: «Religion returns to European society while the modern democracy in Europe rests on the cornerstone of secularism» ${ }^{1}$; ésta es la realidad que deben tener en cuenta las políticas en materia de libertad religiosa, porque los ciudadanos demandan el compromiso estatal que les permita ejercer su derecho de libertad religiosa.

${ }^{1}$ Véase F. Foret e X. ItÇAinA (eds.), «Western European modernities and Religion», en Politics of Religion in Western Europe. Modernities in conflict?, New York, Routledge, 2012. 
En esta tesitura, y debido a que muchos creyentes se someten libremente a las decisiones de sus tribunales religiosos, es donde juega un papel trascendental la actitud estatal hacia el fenómeno religioso; el punto clave donde se puede constatar también el respeto hacia la libertad de religión y la autonomía interna de las confesiones que, mutatis mutandis, es otro modo de respetar el derecho fundamental de libertad religiosa de un ciudadano ${ }^{2}$. Sin embargo, el control estatal sobre las decisiones de estos tribunales interfiere en el desarrollo de este derecho en virtud de la soberanía del Estado sobre ciertas materias como la defensa de los derechos civiles de todos, creyentes o no.

En este trabajo analizaremos la posición de una de las tres grandes religiones en el mundo, conociendo cómo se ha ido pergeñando la posibilidad de que los tribunales religiosos islámicos puedan tomar decisiones relevantes en el ámbito del Derecho privado de un modo no oficial, ya que los Sharia Councils, como el término indica, aplican un derecho religioso, y con los denominados tribunales de arbitraje ${ }^{3}$, aprovechándose de la puesta en vigor de leyes de arbitraje que permiten una resolución alternativa del conflicto.

Como advierte Bower" ${ }^{4}$ "Nowhere in Europe or North America is the legal system closer to recognizing Islamic judgments than in England». El Reino Unido ${ }^{5}$ ha otorgado validez a los acuerdos de arbitraje con diferentes itinerarios legislativos, pero siempre que se respeten ciertas garantías legales y restringiendo su campo de acción en asuntos de matrimonio y familia, donde se genera una particular sensibilidad social y legal ${ }^{6}$. De este nudo temático se desprenden otros núcleos de debate como la problemática generada por los límites en relación con la autonomía interna y el modo en que se ha gestionado el arbitraje religioso, creando new legal cultures.

Por tanto, este trabajo examinará el fenómeno de los tribunales religiosos islámicos, los tribunales islámicos de arbitraje y, en general, la recep-

2 Véase J. BRECHIN, «A study of the use of Sharia Law in religious arbitration in the United Kingdom and the concerns that this raises for human rights», Ecclesiastical Law Journal, vol. 15, núm. 3, 2013, p. 303.

${ }^{3}$ Conocidos en el Reino Unido como Muslim Arbitration Tribunal, se identificarán de ahora en adelante como MAT.

${ }^{4}$ J. R. Bowen, «How could English courts recognize Shariah?», University of St. Thomas Law Journal, vol. 7. núm. 3, 2010, p. 411.

5 Cfr. http://www.legislation.gov.uk/ukpga/1996/23/contents (fecha de consulta: 10 de septiembre de 2013).

${ }_{6}^{6}$ En este sentido, D. HACKER, «Religious tribunals in democratic States: Lessons from the Israeli Rabbinical Courts», Journal of Law and Religion, núm. 27, 2011-2012, p. 59. 
ción del Islam en materia de matrimonio y familia tanto en la legislación como en la jurisprudencia ${ }^{7}$.

\section{EL SISTEMA DE ESTABLISHMENT CHURCH FRENTE AL PLURALISMO LEGAL Y RELIGIOSO}

Tras la ruptura o cisma que separó a la Iglesia de Inglaterra de la Iglesia Católica romana hubo una cierta sintonía en algunos aspectos doctrinales y competenciales ${ }^{8}$, aunque la Iglesia de Inglaterra se atribuyó jurisdicción única en la formación y en la disolución del matrimonio durante varios siglos. Ahora bien, ésta fue más allá al provocar una unión de la Iglesia y el Estado, de modo que, aun siendo de competencia estatal, había cierta connivencia de ambas potestades en esta institución.

En efecto, tras un largo proceso de reformas en el siglo XIX, el matrimonio puede ser celebrado ante las autoridades civiles, no sólo ante las eclesiásticas9. La Matrimonial Causes Act 1857 originó la declaración the Divorce and Matrimonial Causes Bill $1857^{10}$, que atribuye la competencia sobre la disolución o divorcio a la jurisdicción civil. Esta secularización del divorcio intentaba agilizar algunas cuestiones como la custodia de los hijos. A pesar de este traspaso de competencias, la Iglesia de Inglaterra sigue manteniendo especial peso en la formación del matrimonio para sus creyentes.

Actualmente hay dos iglesias principales en el Reino Unido. La Iglesia de Inglaterra se divide en Iglesia anglicana episcopaliana y la Iglesia presbiteriana de Escocia. La primera es gobernada por el Derecho común de Inglaterra, pero también tiene sus propias Measures aprobadas por el sínodo general de la Iglesia, y una vez que se han sometido al voto del comité eclesiástico del Parlamento y sancionados por la Reina

${ }^{7}$ Al igual que explica Sandberg: «It seeks to discuss the current legal position, not only to undermine the hullabaloo which has existed over the last two years, but also so that we can move forward. Before any changes are made in any direction, we need to understand the current position as it is in the law books and as it is interpreted and used on the ground» (R. SANDBERG, «Islam and English law», Law E Justice, núm. 164, 2010, p. 27).

${ }^{8}$ R. H. Helmholz, Roman Canon Law in Reformation England, Cambridge, Cambridge University Press, 1990, pp. 69-70.

9 L. StOne, Road to divorce. England, 1530-1987, Oxford, Oxford University Press, 1990, pp. 183-210.

${ }_{10} \mathrm{Cfr}$. bttp://ecclesiasticallaw.wordpress.com/tag/divorce-and-matrimonial-causesact-1857/ (fecha de consulta: 30 de septiembre de 2013). 
entran en vigor mediante ley del Parlamento ${ }^{11}$. Los tribunales de la Iglesia de Inglaterra pueden resolver sus propios asuntos en virtud de la autonomía interna.

Durante la vigencia de las leyes contra la blasfemia se denunció que no había espacio legal para otras religiones ${ }^{12}$. La tolerancia y la libertad religiosa eran una asignatura pendiente a pesar de la existencia de una ley de tolerancia desde el año $1689^{13}$. Quizá por este motivo, Trigg ${ }^{14}$ se pregunta no hasta qué punto es cristiana Inglaterra, sino si debería serlo, y trae a colación la jurisprudencia del Tribunal de Estrasburgo en la que se reclama la neutralidad estatal para mantener el respeto al pluralismo.

La tolerancia y el respeto se afianzan con la ratificación de la Declaración Universal de Derechos Humanos de 1948 y de la Declaración de las Naciones Unidas de 1981 sobre la eliminación de la intolerancia y la discriminación basada en la religión o creencia ${ }^{15}$.

Con la Race Relation Act 1976 se protegía a los judíos y a los sijs de toda discriminación, pero quedaban excluidos los demás, como católicos o musulmanes. Fue necesario esperar a la normativa The Employment Equality (Religion or Belief) Regulations 2003, que prohibía la discriminación en el lugar de trabajo por razón de religión, creencia religiosa o convicciones filosóficas. Actualmente, otros grupos religiosos coexisten en el mismo país con distintos valores ${ }^{16}$, pero en un contexto de respeto hacia la libertad religiosa ${ }^{17}$, de no discriminación por razón de religión y en un marco

11 Véase I. M. Briones MartíneZ, «Conciencia y sacerdocio femenino en la Iglesia de Inglaterra», Revista española de Derecho Canónico, vol. 54, núm. 143, 1997, p. 647-682.

12 «Most legal provisions are, however, implicitly based on the Christian faith or Christian ethics, and can therefore sometimes hamper the free observance of the worship of other religions» (VVAA, Western Europe and its Islam, Leiden-Boston-Köln, Brill, 2001, p. 229). Véase también R. NAVARro VAlls, «Europa, Cristianismo y Derecho», en VVAA, Pluralismo religioso y Estado de Derecho, Madrid, Cuadernos de Derecho Judicial, 2004, p. 400.

13 P. CUMPER, «The United Kingdom and the UN Declaration on the Elimination of Intolerance and Discrimination Based on Religious or Belief», Emory International Law Review, núm. 21, 2007, p. 15.

${ }^{14}$ Leyla Sahin vs. Turkey (2005) ECHR 4474/98 at para. 107. Véase R. TRIGG, «Religion in the public forum», Ecclesiastical Law Journal, vol. 13, núm. 3, 2011, pp. 274 y 276.

15 W. A. R. Shadid y P. S. Van Koningsveld, Religious freedom and the position of Islam in Western Europe. Opportunities and obstacles in the acquisition of equal rights, Peeters, Leuven, 1995, p. 19.

16 Véase S. BANO, «Islamic Family Arbitration, Justice and Human Rights in Britain», Law, Social Justice E Global Development Journal, vol. 1, 2007, p. 2.

17 «Archbishop Justin told his audience that diversity was a "gift not a threat" and he did not want to live in a "monocultural" society. He said he "rejoiced" in the example of inter faith co-operation and community work he had witnessed». Cfr. http://www.archbishopofcan 
legal de neutralidad estatal, rompiendo con la doctrina «The Church and State are indivisible» propuesta por los Tory ${ }^{18}$.

El Reino Unido garantiza la libertad religiosa de los grupos religiosos a través de la sección 13 de la Ley de Derechos Humanos de $1998^{19}$, dictada en ejecución del Convenio Europeo de Derechos Humanos y Libertades Fundamentales (CEDH), que tiene en cuenta las necesidades religiosas colectivas e individuales de la sociedad ${ }^{20}$. Además, el art. 9 de la Ley refuerza la protección de la libertad religiosa ejercida solo o en comunidad, en público o en privado ${ }^{21}$.

El Tribunal Europeo de Derechos Humanos (TEDH) es una válvula de seguridad para la protección de los derechos individuales y colectivos, pero en ocasiones aplica un criterio restrictivo, sobre todo en materia de símbolos religiosos ${ }^{22}$. Sentencias europeas tan restrictivas que, como irónicamente afirma Cumper, hubieran podido pasar por británicas ${ }^{23}$.

El TEDH, basándose en el apartado segundo del art. 9 CEDH, se mantiene a favor de la autonomía interna de las comunidades religiosas ${ }^{24}$, pero

terbury.org/articles.php/5112/diversity-is-a-gift-says-archbishop-justin-during-visit-to-southall (fecha de consulta: 11 de septiembre de 2013).

${ }_{18}$ R. M. Morris (ed.), Church and State in $21^{\text {st }}$ Century Britain. The Future of Church Establishment, Hampshire, Basingstoke, 2009, p. 20.

19 «13. Freedom of thought, conscience and religion: (1) If a court's determination of any question arising under this Act might affect the exercise by a religious organization (itself or its members collectively) of the Convention right to freedom of thought, conscience and religion, it must have particular regard to the importance of that right. (2) In this section "court" includes a tribunal». Cfr. bttp://www.legislation.gov.uk/ukpga/1998/42/section/13 (fecha de consulta: 8 de julio de 2013).

${ }^{20}$ Véase Sunday Times vs. UK (1979) 2 EHRR 245 AT 107.

${ }^{21}$ «Article 9. Freedom of thought, conscience and religion: (1) Everyone has the right to freedom of thought, conscience and religion; this right includes freedom to change his religion or belief and freedom, either alone or in community with others and in public or private, to manifest his religion or belief, in worship, teaching, practice and observance. (2) Freedom to manifest one's religion or beliefs shall be subject only to such limitations as are prescribed by law and are necessary in a democratic society in the interests of public safety, for the protection of public order, health or morals, or for the protection of the rights and freedoms of others». Cfr. bttp://www.legislation.gov.uk/ukpga/1998/42/schedule/1 (fecha de consulta: 8 de julio de 2013).

${ }^{22}$ Copsey vs. WWB Devon Clays Ltd. (2005) EWCA (Civ) 932 (Eng.); un empleado cristiano que se niega a trabajar en domingo, Steadman vs. United Kingdom, App. No. 29107/95, 23 Eur. H.R. Rep. 168 (1997); sobre el velo islámico de una profesora, $R$ (on the application of Begum) vs. Headteacher E Governors of Denbigh High School (2006) UKHL 15 (appeal taken from Eng.). Un caso similar ante el TEDH, Leyla Sahin vs. Turkey, 41 Eur. Ct. H.R. 8 (2005).

${ }^{23}$ P. Cumper, «The United Kingdom and the UN Declaration on the Elimination of Intolerance and Discrimination Based on Religious or Belief», op. cit., p. 18.

${ }^{24}$ Véase en el mismo sentido, otorgando libertad para promover la uniformidad en 
respeta el margen de discrecionalidad en la regulación estatal de los grupos religiosos siempre que el Estado actúe en consecuencia con las exigencias de su neutralidad y con el único fin de procurar el respeto y la tolerancia entre las religiones, y no pretendiendo eliminar el pluralismo ${ }^{25}$.

No obstante, el papel neutral del Estado es incierto cuando se trata de cuestiones internas, de decisiones judiciales o de acuerdos de arbitraje que constituyen Derecho pero se fundamentan en tradiciones religiosas o en un texto sagrado, como ocurre con la Sharia ${ }^{26}$. Es en este punto donde aparece la encrucijada: respetar la autonomía interna de las confesiones, presumiendo el consenso (consensual compact) de las partes implicadas, o intervenir porque la decisión o el acuerdo viola los derechos civiles de las personas, que deben ser siempre garantizados sin distinción por razón de religión o de sexo, en casos como la violencia física o psíquica, la injusta distribución de la propiedad, la desigualdad de derechos que produce la poligamia u otros como el igual acceso a la justicia y la debida tutela judicial ${ }^{27}$.

En la otra cara de la moneda, también resulta controvertido el hecho de juzgar en un tribunal secular sobre un aspecto de significado religioso. Pilgram ${ }^{28}$ comenta el caso conocido como the missing pound, Ali vs. Ali (2000), al que califica como un completo escenario multicultural. Los esposos firmaron un contrato en el que fijaron la dote en 30.001 libras. Poco tiempo después del matrimonio el marido solicita el divorcio ante los tribunales británicos y también la repudia mediante un talaq.

el culto, la enseñanza, la práctica y la observancia de la religión, $X$ vs. Denmark, App No. 7374/76, 5 DR 157 (1976); X vs. United Kingdom, App No. 8160/78, 22 DR 27 (1981), y Knuden vs. Norway, App No. 11045/84 (1985).

${ }_{25}$ Así se resolvió en el caso Supreme Holy Council vs. Bulgaria, App No. 39023/97 (2005). Cfr. http://hudoc.echr.coe.int/ (fecha de consulta: 6 de noviembre de 2013).

${ }^{26}$ «Sharia determines how certain aspects of everyday life are to be practiced according to the model provided by the canon» (R. WHEELER, Applying the canon in Islam: the authorization and maintenance of interpretative reasoning in Hanafi Scholarship, Albany, Albany State University Press, 2008, p. 34).

${ }^{27}$ En el Reino Unido sólo se da validez a los acuerdos de arbitraje si se atienen a lo establecido en la Arbitration Act 1996: «Enforcement of peremptory orders of tribunal: (1) Unless otherwise agreed by the parties, the court may make an order requiring a party to comply with a peremptory order made by the tribunal. (2) An application for an order under this section may be made: (a) by the tribunal (upon notice to the parties), (b) by a party to the arbitral proceedings with the permission of the tribunal (and upon notice to the other parties), or (c) where the parties have agreed that the powers of the court under this section shall be available. (3)The court shall not act unless it is satisfied that the applicant has exhausted any available arbitral process in respect of failure to comply with the tribunal's order» (c. 23 \& 42).

${ }^{28}$ L. Pilgram, «Responses to Muslim law in the UK: Fro ethno-religious sensitivity to "supplementary jurisdiction"», en G. BIFfL y L. RössL (eds.), Migration und Integration, Wien, Guthmann-Peterson, 2011, p. 110. 
La señora Ali reclama que se le entregue la dote debida, a lo que el señor Ali se opone porque se debe aplicar el Derecho inglés que no incorpora la figura de la dote en el Derecho matrimonial ni otorga validez a los acuerdos prenupciales ${ }^{29}$.

El tribunal se asesoró con un experto en Derecho musulmán y, previendo dos circunstancias probables, consideró aplicable el acuerdo. Se tuvo en cuenta la situación de injusticia y desprotección que supondría para la mujer, ya que la dote sería el único sustento económico, y también se vaticinó que terminaría solicitando justicia a un consejo de Sharia, de ahí que se fijó la cantidad de 30.000 libras que debían ser entregadas en concepto de dote. Al restar una libra a la cantidad fijada en el acuerdo prenupcial (the missing pound) da a entender que no se aplica el Derecho musulmán y que tampoco se traiciona la jurisprudencia inglesa en materia de acuerdos prenupciales.

Menski ${ }^{30}$, se cuestiona el motivo de esta solución ecléctica porque en otros casos se había pronunciado aplicando un derecho religioso, y pone como ejemplo a Chief Adjudication Officer vs. Bath (2000) ${ }^{31}$. El Tribunal de Apelación reconoce el derecho a recibir una pensión por parte de la viuda en el caso de un matrimonio sij que había tenido lugar en un templo sij de Londres treinta y cinco años antes, pero nunca había sido registrado oficialmente como matrimonio ante las leyes de Inglaterra. El Tribunal no declaró nulo el matrimonio, sino que extendió la presunción de ley de pareja casada a la larga cohabitación de esta pareja. Para Menski, se aplicó la conocida equity en Derecho inglés, y para Hodson, se combinan otros factores: "The Court balances marriages which would be "offensive to the conscience of the English Courts" [Cheni (otherwise Rodriguez) vs. Cheni (1962) 3 All ER 873] with the need for "common sense, good manners and reasonable tolerance" and international comity ${ }^{32}$.

El gran reto es el de crear una relación constructiva entre el derecho religioso de las minorías especialmente y el derecho secular del Reino Unido, que algunos basan en una «acomodación mutua». Este enfoque ya

\footnotetext{
${ }^{29}$ Salvo excepciones como el caso Radmacher vs. Granatino, Court of Appeal (2010) UKSC 42, y Granatino vs. Radmacher (2011) AC 534, Supreme Court.

${ }^{30}$ W. F. MENSKI, «Immigration and multiculturalism in Britain: New issues in research and policy», http://www.casas.org.uk/papers/pdfpapers/osakalecture.pdf(fecha de consulta: 9 de septiembre de 2013), pp. 5-7.

${ }^{31}$ Chief Adjudication Officer vs. Bath, 2000 (1) Family Law Reports, page 8, the Court of Appeal.

32 D. Hodson, «Recognition of foreign marriages and divorces», http://www.davidhodson.com/assets/documents/recognition.pdf (fecha de consulta: 9 de septiembre de 2013).
} 
ha sido enfrentado en otros países como Irlanda, Canadá33 o Estados Unidos, y en el peculiar sistema legal de Israel. Sin embargo, no se trata sólo del régimen jurisdiccional, en el que se ha iniciado la tendencia a evitar la esterilidad de monopolios exclusivos, sino de lidiar con cuestiones que tienen un carácter teológico y pueden no ser negociables ${ }^{34}$. De ahí que la acomodación vendría más bien del esfuerzo de la parte contraria, una sustantiva acomodación del derecho secular a las demandas religiosas; operación que debe realizarse dentro y como una parte del proceso democrático. Esta acomodación no debería privar a los miembros de una comunidad religiosa de sus derechos civiles, y es aquí donde entraría otra vez el dilema del conflicto jurisdiccional, por lo que la idea de un acuerdo consentido mediante arbitrio es suscrita más positivamente que la de dar fuerza legal a decisiones judiciales de tribunales religiosos, aunque también se ha visto franqueada por las prevenciones legales de Occidente.

\section{ENFOCANDO EL DEBATE DE LOS TRIBUNALES RELIGIOSOS Y EL PLURALISMO LEGAL COMO EXPRESIÓN DE IDENTIDAD Y DEL PRINCIPIO DE AUTONOMÍA}

\section{Autonomía de las confesiones}

Otaduy ${ }^{35}$ advierte sobre la incuestionable realidad de que los ordenamientos del Estado y de las confesiones pertenecen a dos órdenes diversos -el político y el religioso-, y, por tanto, el Estado como las confesiones se declaran soberanos en el propio e incompetentes en el ajeno. Ambos órdenes, sin embargo, no se encuentran incomunicados, porque arraigan en la persona humana, que es a la vez sujeto y fundamento del orden políti-

33 El gobierno de Ontario aprobó una ley, Family Statute Law Amendment Act 2006, la cual enmendó la Arbitration Act 1991 y fue implementada por otra ley, Family Arbitration Act 2007, con el fin de evitar un sistema de arbitraje que fuera en detrimento de las personas más vulnerables. En esta ley se recogían las recomendaciones de Marion Boyd en su informe sobre el arbitraje «Dispute resolution in family Law. Protecting choice, promoting inclusion», diciembre de 2004. Cfr. http://www.attorneygeneral.jus.gov.on.ca/english/about/pubs/ boyd/ (fecha de consulta: 11 de julio de 2013).

${ }_{34}$ M. KING (ed.), God's Law versus State Law: The Construction of an Islamic Identity in Western Europe, London, Grey Seal, 1995.

35 J. OTADUY, «Autonomía de las confesiones religiosas. Las cláusulas de salvaguarda de la identidad de las confesiones», en Derecho canónico y Derecho eclesiástico del Estado, III, Eclesiástico, ed. electrónica, Madrid, Iustel, pp. 2-3. 
co y del orden religioso ${ }^{36}$. Aunque Otaduy analiza el fenómeno en el espacio español con respecto a la Iglesia Católica y considera que el ordenamiento religioso no es derivado o secundario del estatal ${ }^{37}$, este asunto es espinoso y conflictivo en otros países respecto a otras religiones, como se ha visto en el Reino Unido tras las declaraciones del exarzobispo de Canterbury, Rowan Williams, sobre las que trabajaremos más adelante.

Podríamos pensar que el reconocimiento de la autonomía interna de las confesiones se asume únicamente en países donde impera el principio de cooperación en un marco de laicidad y democracia, como es el caso de España; sin embargo, siguiendo los estudios de Robberts ${ }^{38}$, Scharffs ${ }^{39}$ y Warnink ${ }^{40}$, así como el razonamiento de Puppinck ${ }^{41}$ en su análisis de la jurisprudencia de Estrasburgo, su existencia es independiente al marco de relaciones Iglesia-Estado y anterior al propio Convenio Europeo.

La gran sala del TEDH está entonces a favor del respeto del principio de autonomía interna ${ }^{42}$, porque contribuye a garantizar la paz religiosa ${ }^{43}$ como una manifestación del respeto a la libertad de religión de la institución y a la libertad religiosa de sus miembros ${ }^{44}$, tal y como se desprende del contenido del art. 11 del Convenio Europeo.

36 Ibid., p. 5.

${ }^{37}$ Ibid., p. 7.

38 G. RobBers, Church Autonomy. A Comparative Survey, Berlin, Peter Lang, 2001.

39 B. SCHARFFs, «The Autonomy of Church and State», Brigham Young University Law Review, núm. 4, 2004, pp. 1217-1348.

${ }^{40} \mathrm{H}$. Warnink, Legal Position of Churches and Church Autonomy, Serie Scripta Canonica, núm. 3, Leuven, Isd, 2001.

${ }^{41}$ G. PUPPINCK, «El principio de autonomía de la Iglesia Católica ante el Tribunal Europeo de Derechos Humanos. El caso Fernández Martínez contra España», Revista General de Derecho Canónico y Derecho Eclesiástico del Estado, núm. 28, 2012, pp. 18-19.

${ }^{42}$ STEDH, 26 de octubre de 2000, núm. 30985/96, Hassan y Tchaouch vs. Bulgaria (GC), \& 84, TEDH 2000-XI, p. 62.

${ }^{43} \mathrm{Si}$ en un caso la imparcialidad no pretende «suprimir la causa de las tensiones mediante la eliminación del pluralismo, sino velar para que los grupos contrincantes se toleren los unos a los otros» contribuyendo de esta manera a «garantizar el orden público, la paz religiosa y la tolerancia en una sociedad democrática», el respeto del principio de autonomía alude primeramente al respeto de la libertad religiosa de la comunidad y de sus miembros y contribuye solamente, por consiguiente, a garantizar la paz religiosa. Véanse CEDH, Serif, $\$ 53$; CEDH, Metropolitan Church of Bessarabia and others, $\mathbb{\$} 116$; CEDH, 17 de octubre de 2002, Agga vs. Grecia, núm. 2, \$59; CEDH, 22 de enero de 2009, San Sínodo de la Iglesia ortodoxa builgara (Metropolita Innocent) vs. Bulgaria, $\mathbb{\$} 159$. Cfr. el comentario en bttp:// eclj.org/PDF/ECLJ-OBSERVATIONS-CEDH-FERNANDEZ-MARTINEZ-contre-ESPAGNE -TRAD-ESPAGNOLE.pdf (fecha de consulta: 20 de enero de 2014).

${ }_{44}$ En efecto, la autonomía de las comunidades religiosas es indispensable para el pluralismo en una sociedad democrática y, por tanto, está bajo la protección que ofrece el art. 9. Presenta un interés directo no solamente para la organización de la comunidad como tal, 
Ahora bien, cuando se enfrentan la autonomía personal y la autonomía institucional no directamente, sino bajo la percepción del Estado, el quid está en determinar si la materia en cuestión es de naturaleza civil o religiosa. Si estamos ante el matrimonio, la disolución del vínculo, la nulidad o asuntos que afecten a los menores de edad navegamos entre lo público y lo privado, entre el carácter religioso y civil.

Si en el matrimonio islámico y la disolución del mismo se plantea la desigualdad de los esposos, tales diferencias sólo serán admisibles si no van en contra de los principios constitucionales de los Estados y de los principios generales del Convenio Europeo ratificados por los mismos, como es el caso del Reino Unido.

Como señala también Puppinck, el Tribunal Europeo se ha enfrentado a esta cuestión especialmente cuando se trata de apreciar la legitimidad de obligaciones que se desprenden de la Sharia, y hace referencia a la ablación, el castigo de los apóstatas y al pañuelo islámico, con especial atención a la sentencia Leyla Sabin vs. Turquía ${ }^{45}$.

\section{Cuestiones de conciencia individual y consensuada como parte del derecho a la autonomía}

El exarzobispo de Canterbury, Rowan Williams ${ }^{46}$, se refirió en sus declaraciones a las cuestiones de conciencia, que es el núcleo fundamental de esta materia:

«I hoped also, though, to raise a wider question about the relation between faith and law. We have taken it for granted that the law protects the consciences of religious believers, and all that I said last week needs to be read in that context (I mentioned the conscience clauses about abortion in the medical professions). So, while there is no dispute about our common allegiance to the law of the land, that law still recognizes that religious communities form the consciences of believers and has not pressed for universal compliance with aspects

sino para el goce efectivo para el conjunto de sus miembros activos del derecho a la libertad de religión. Si la organización de la vida de la comunidad no estuviera protegida por el art. 9 del Convenio, todos los demás aspectos de la libertad de religión del individuo estarían debilitados (ibid., $\$ 62$ ).

${ }^{45}$ STEDH, 29 de junio de 2004, núm. 44774/98, Leyla Sabin vs. Turquía. Cfr. bttp:// budoc.echr.coe.int/ (fecha de consulta: 20 de enero de 2014).

46 Véase R. Williams, «Civil and Religious Law in England: A Religious Perspective», Ecclesiastical Law Journal, vol. 10, núm. 3, 2008, pp. 262-282. 
of civil law where conscientious matters are in question. However, there are signs that this cannot necessarily be taken quite so easily for granted as the assumptions of our society become more secular. I think we ought to keep an eye on this trend; and if we do, we shall have to do more thinking about the models of society and law we work with. It's an area where Christians and people of other faiths ought to be doing some reflecting together» ${ }^{47}$.

Andrea Büchler considera que se debe conceder autonomía a las personas para decidir el Derecho aplicable ${ }^{48}$. Sin embargo, en la elección personal también se discute la «capacidad para elegir sin ser coaccionado», sobre todo en materia de familia, y es por ello que en las confesiones religiosas es donde se ha centrado siempre todo el arsenal de artillería contra la autonomía interna ${ }^{49}$.

Helfand ${ }^{50}$ advierte que el poder que se otorgue a las religiones será como un zero-sum game, que colocará en desventaja a las personas singulares para reclamar sus derechos civiles.

Con una proyección diferente, Ahmed señala que la autonomía del grupo promueve la libertad religiosa de los miembros ${ }^{51}$. Ciertamente, la

${ }^{47}$ Cfr. http://rowanwilliams.archbishopofcanterbury.org/articles.php/1326/presidentialaddress-to-the-opening-of-general-synod-february-2008 (fecha de consulta: 11 de septiembre de 2013).

48 «Basing applicable law on the individual's closest social and cultural ties — called the "better law" or "proper law" approach_- permits a case-by-case determination, though this places considerable undirected and unstructured powers in the bands of the courts. Such an approach can also impinge considerably on the predictability of the outcome, since the territorial and personal coverage of a law in open to judicial discretion. Possibilities for allowing the individual to choose the law which is applied do, however, constitute a promising alternative approach in this regard. The concept of party autonomy is gaining increasing support, particularly as a means of constraining the nationality principle and of precluding any unpredictability and uncertainty with respect to the conflict - of - laws rules and legal norms to which the parties are expected to comply. Giving the parties the freedom to choose applicable law relies on their will and their willingness to exercise that freedom, and trusts that they will autonomously reach the best decision as to which legal system is appropriate for governing their relationship» (A. BüCHER, Islamic Law in Europe. Legal Pluralism and its limits in European Family Laws, Aldershot, Ashgate, 2011, pp. 38-39).

${ }^{49} \mathrm{La}$ autonomía interna de los grupos exige una mínima gobernanza democrática que la mayoría de las religiones no tienen en su estructura.

50 «That power under such circumstances, becomes a zero-sum game, where the more power the government grants to religious and cultural groups, the more difficult it will be for an individual religionist to access the fundamental rights granted by the state» (M. A. HeLFAND, «Religious Arbitration and New Multiculturalism: negotiating, conflicting legal orders», New York University Law Review, vol. 86, 2011, p. 1276).

${ }^{51}$ F. Ahmed, «Religious Norms in Family Law», en M. Maclean y J. EekelaAr (eds.), Managing Family Justice in Diverse Societies, Oxford, Hart Publishing, 2013, pp. 38-46. 
autonomía de los grupos exige una mínima gobernanza democrática que la mayoría de las religiones no tienen en su estructura, pero se han ido desligando de la sombra de la opresión o coerción con la teoría propuesta como «consensual compact» ${ }^{52}$. A través de la doctrina de la libre adherencia y de una fe compartida puede llegar a considerarse una obligación legal a nivel individual o de asociación ${ }^{53}$, ya se trate de reglas sobre servicios prestados a la iglesia, de una decisión de un tribunal religioso o de un tribunal de arbitraje sobre asuntos privados de familia, o una cláusula contractual en torno a temas de propiedad pactada por personas que comparten la misma fe de modo consensuado y de conformidad con la Constitución de la Iglesia a la que pertenecen ${ }^{54}$.

En todo caso, la doctrina consensual compact no significa que los mismos miembros pertenecientes a una confesión no puedan poner en tela de juicio las decisiones de un tribunal religioso; de hecho, pueden reclamar sus derechos ante un tribunal secular, incluso demandar ante la justicia supranacional ${ }^{55}$.

Sin embargo, se imponen límites a la autonomía interna institucional para proteger a los ciudadanos creyentes. El Estado no tiene un interés legítimo en el contenido y en la aplicación del derecho religioso dentro de los tribunales religiosos que aplican la Sharia y que son llamados «guardians of the faith» ${ }^{56}$; el único y legítimo interés se basa en el impacto que las decisiones de estos tribunales puedan tener sobre los derechos civiles y, en general, todos sus aspectos seculares.

Veamos dos ejemplos. El primer ejemplo lo encontramos en el delito de jurisdicción falsa que se prescribe en el s. 7 de la ley conocida como The English Arbitration and Mediation Services (Equality) Bill 2010. Con esta ley

52 Véase el análisis de Long vs. Bishop of Capetown and others cases por N. Cox, «The Symbiosis of Secular and Spiritual Influences upon the Judiciary of the Anglican Church in New Zealand», Deakin Law Review, vol. 9, núm. 1, 2004, pp. 145-182.

53 Como se comprueba en Davies vs. Presbyterian church of Wales (1986) 1 WLR 323, como ejemplo de respeto a la autonomía interna de las iglesias.

54 Scandrett vs. Dowling (1992) 27 NSWLR 483. «This case remains one of the leading cases with respect to the circumstances in which an enforceable legal obligation is created by church rules» (J. MartíneZ TORRÓN y W. Cole Durham Jr., Religion and the Secular State. Interim national reports, XVIII The International Congress of Comparative law, Washington DC, 2010, p. 98).

55 (2001) ECHR 480. HRA 1998. Recordemos el caso Pellegrini vs. Italy que puede afectar a todos aquellos países de la Unión Europea como Italia, España, Portugal y Malta que, habiendo ratificado el Convenio Europeo de Derechos Humanos, también tienen tribunales eclesiásticos dentro de su propio territorio nacional.

56 A. SHACHAR, «Privatizing diversity: a cautionary tale from religious arbitration in family Law», Theoretical Inquiries in Law, vol. 9, núm. 2, 2008, p. 587. 
se pretende prohibir a quienes toman decisiones en los tribunales religiosos de minusvalorar la validez de las decisiones de tribunales seculares. El Estado tiene un legítimo interés en prevenir el fraude, especialmente el que consiste en impedir a todos los ciudadanos el acceso a la justicia estatal.

El segundo ejemplo es el del s. 10A de la Matrimonial Causes Act 1973, la cual otorga competencia a los tribunales civiles para impedir que un varón pueda usar su poder en materia de género, en cuanto esposo musulmán, para rechazar un divorcio, para influir en las negociaciones que se lleven en un procedimiento de divorcio civil o para restringir el derecho de su esposa para volver a casarse. Debido a que la violencia de género no se refiere sólo al ataque físico, en este caso el Estado está intentando tomar ventajas para prevenir estas situaciones tanto en el contexto religioso como en el no religioso.

\section{El arbitraje como conciliación entre la autonomía institucional y personal}

Ciertamente, hay una tendencia a privatizar el derecho de familia en nombre de la religión ${ }^{57}$ y del derecho religioso, por lo que las decisiones de los tribunales religiosos pueden dar lugar a una confrontación de intereses jurídicos conocido en el mundo anglosajón como el fenómeno de clashing rights ${ }^{58}$.

De cara a evitar una situación quimérica se dicta la Ley de Arbitraje en el año $1996^{59}$ como intento de razonable acomodación, un remedio para encontrar soluciones a disputas legales entre las partes contendientes evitando la demora judicial y los costes de la misma, tanto monetarios como morales, de ahí que a las decisiones de tribunales religiosos de arbitraje basadas en esta ley se las conozca como faith-based arbitration.

57 R. Fretwell WiLSON, «Privatizing family law in the name of Religion», William \& Mary Bill of Rights Journal, vol. 18, 2009-2010, pp. 925-953.

58 «In short, the mandatory religious rights standards and codes of conduct, pillars of different cultures, claiming cultural and interfaith mediation which some experts claim repeatedly, since the only relevant official bodies to promote harmonious relationships are "Commission of racial Equality and the Equal Opportunities Commission", but its powers relating to issues of racial and sexual discrimination, which indirectly comprehend religious elements, not contemplating the urge interfaith dialogue, or at least, cultural mediation in UK» [U. KHALIQ, «Islam and the European Union: Report on the United Kingdom», en R. POtZ y W. Wieshaider (eds.), Islam and the European Union, Leuven, Peeters Publishers, 2004, pp. 253-254].

${ }_{59}$ Cfr. bttp://www.legislation.gov.uk/ukpga/1996/23/contents (fecha de consulta: 13 de septiembre de 2012). 
Nos encontramos, por tanto, ante una nueva realidad legal y social en el Reino Unido, lo que Menski denomina new legal bybrids ${ }^{60}$.

Esta híbrida situación legal y social aplicada al arbitraje es valorada positivamente por el exarzobispo de Canterbury como un instrumento alternativo para la resolución de disputas, y así lo hizo notar:

«The MAT could establish a symbiotic relationship with the judiciary in regulating justice through the British system, reflective of society's values, while empowering Muslims to generate grassroots solutions to community issues through alternative dispute resolution» ${ }^{61}$.

Debido a la envergadura de las consecuencias sociales y jurídicas de este tipo de resolución de conflictos, en el Reino Unido todas estas decisiones judiciales o arbitradas deban ser contrastadas con la Ley de Derechos Humanos de 1998 y su normativa de ejecución o desarrollo ${ }^{62}$.

Ahora bien, hay un pronunciamiento en favor del arbitraje religioso: se pueden invocar las normas y principios de un derecho religioso como si constituyeran otro derecho aplicable ${ }^{63}$ sólo en virtud de una cláusula de arbitraje. Así, el ministro de Justicia en su Practice Direction-Pre-Action Conduct ${ }^{64}$ menciona el arbitraje como una solución alternativa de dispu-

60 W. Menski, Legal traditions of the world. Oxford University Press, 2007, p. 248.

${ }^{61}$ Citado por B. M. СнокsI, «Religious arbitration in Ontario-making the case based on the British example of the Muslim Arbitration Tribunal», University of Pennsylvania Journal of International Law, vol. 33, núm. 3, 2012, pp. 814-815.

62 Varias sentencias inglesas establecen la conexión entre arbitraje y la ley de derechos humanos: Stretford vs. Football Association (2007) All ER (D) 346; Sumukan Ltd vs. The Commonwealth Secretariat (2007) EWCA Civ 243, y Shuttari vs. The Solicitors Indemnity Fund (2007) APP.L.R 03/21.

${ }_{63}$ Véase, sobre la elección del derecho aplicable en finanzas, J. C. CoLÓN, «Choice of Law and Islamic Finance», Texas International Law Journal, vol. 46, 2010-2011, pp. 411 y ss.

${ }^{64}$ «8. Alternative Dispute Resolution:

8.1. Starting proceedings should usually be a step of last resort, and proceedings should not normally be started when a settlement is still actively being explored. Although ADR is not compulsory, the parties should consider whether some form of ADR procedure might enable them to settle the matter without starting proceedings. The court may require evidence that the parties considered some form of ADR (see paragraph 4.4(3)).

8.2. It is not practicable in this Practice Direction to address in detail how the parties might decide to resolve a matter. However, some of the options for resolving a matter without starting proceedings are: (1) Discussion and negotiation; (2) Mediation (a form of negotiation with the belp of an independent person or body); (3) Early neutral evaluation (where an independent person or body, for example a lawyer or an expert in the subject, gives an opinion on the merits of a dispute); or (4) Arbitration (where an independent person or body makes a binding decision), many types of business are members of arbitration schemes for resolving disputes with consumers. 
tas. La resolución arbitrada puede tener forma de contrato privado entre las partes que deciden mutuamente someterse a la decisión de un árbitro o el acuerdo de someterse a un tribunal religioso para que se tome una decisión. También hay formas intermedias que concilian la mediación y el arbitraje.

Con independencia del tema sustancial de fondo sobre la convivencia de varios sistemas legales, seculares y religiosos en el mismo territorio, lo cierto es que el sistema de arbitraje puramente como una alternativa de resolución de conflictos tiene sus ventajas y desventajas ${ }^{65}$.

Siguiendo a Litt Wolfe ${ }^{66}$, entre las principales ventajas del arbitraje como alternativa de resolución de conflictos están las siguientes: 1) La privacidad. Las sesiones no están abiertas al público. 2) Las reglas aplicables son más flexibles y se permite a las partes elegir las reglas y procedimientos. 3) El procedimiento se asimila más a un negocio que a un juicio oficial con abogados, ya que se lleva a cabo en una sala privada de conferencias. 4) Como el procedimiento de apelación es más limitado se busca directamente la solución más que la continuidad del litigio. 5) El arbitraje permite a ambas partes presentar sus argumentos en un foro neutral. 6) Las partes descansan en la decisión de un árbitro experto en la materia sobre la que se decide. 7) El árbitro es capaz de encontrar siempre un remedio a la situación, etc.

De conformidad con el parágrafo 23 de las reglas de procedimiento del MAT, no habrá apelación contra las decisiones tomadas por estos tribunales, pero se puede solicitar una revisión judicial con permiso del Alto Tribunal ${ }^{67}$. Aun así, hay cierta prevención hacia lo que no se pueda juzgar

8.3. The Legal Services Commission has published a booklet on "Alternatives to Court", CLS Direct Information Leaflet 23 (www.clsdirect.org.uk) which lists a number of organizations that provide alternative dispute resolution services. The National Mediation Helpline on 08456030809 or at www.nationalmediationhelpline.com can provide information about mediation.

8.4. The parties should continue to consider the possibility of reaching a settlement at all times. This still applies after proceedings have been started, up to and during any trial or final hearing». Cfr. bttp://www.justice.gov.uk/courts/procedure-rules/civil/rules/pd_pre-action_ conduct (fecha de consulta: 6 de noviembre de 2013).

${ }^{65}$ Véase, sobre ventajas e inconvenientes del arbitraje y del proceso judicial en la experiencia española y el arbitraje internacional, R. HinOJOSA SEGOVIA, «Arbitraje nacional: la experiencia española», Revista de Derecho Procesal, núm. 1, 2000, pp. 86-93.

66 C. LitT Wolfe, «Faith based arbitration: friend or foe? An evaluation of religious arbitration systems and their interaction with secular courts», Fordham Law Review, vol. 75, 2006-2007, p. 431.

${ }^{67} \ll \$ 23$. No appeal shall be made against any decisions of the Tribunal. This rule shall not prevent any party applying for Judicial Review with permission of the High Court». Cfr. 
directamente por un tribunal secular, o que no exista un modo directo de supervisar el procedimiento, o el hecho de que no tengan un registro de sentencias para basarse en precedentes, lo que dificulta la uniformidad en las decisiones, y otros inconvenientes similares, además de los temas singulares de género ${ }^{68}$.

Para Menski ${ }^{69}$, la justicia de los tribunales religiosos no minusvalora la supremacía de la ley estatal y supone la aceptación de principios universales como la legalidad, la justicia y la igualdad ante la ley, una especie de común ciudadanía en una sociedad con un background cultural, religioso y étnico diferente.

Sin embargo, en el proyecto Religious diversity and secular models in Europe presentado en RELIGARE se plantean las Resoluciones Alternativas de Disputas o Conflictos (ADR) como una demanda pública de rechazo al derecho secular e imposición de la ley islámica sin condiciones ${ }^{70}$. Se menciona el libro titulado Rules of Personal Status of Muslim in the WestInnovative approaches to Law and Policy, en el que Salim Ibn declara que los no musulmanes son infieles y rechaza tanto la normativa como las sentencias alemanas por ser reglas de infidelidad; también defiende la necesidad de aplicar el castigo por adulterio apedreando hasta morir a las mujeres que se casen con varones no musulmanes; del mismo modo, denuncia el sistema de la seguridad social por conceder independencia a las mujeres, lo que les otorga capacidad para desobedecer a sus maridos por la independencia que suponen las pensiones de carácter social.

En medio de un huracán de vientos a favor o en contra, y aunque resulte sorprendente, las decisiones arbitradas en materia fiscal, económica o comercial se asumen de modo prioritario ${ }^{71}$. Estamos acostumbrados, y, de hecho, será el núcleo central de este trabajo, a estudiar los comprometidos asuntos en materia de familia, pero la Ley de Arbitraje de 1996 ha dado

http://www.matribunal.com/procedure_rules.html (fecha de consulta: 10 de septiembre de 2013).

${ }^{68}$ Véase Values and equalities of MAT. Cfr. http://www.matribunal.comvalues.html (fecha de consulta: 10 de septiembre de 2013).

69 W. Menski, «Muslim Law in Britain», Journal of Asian and African Studies, vol. 62, 2001, p. 202.

${ }_{70}$ M. RoHE, «Alternative Dispute Resolution in Europe under the auspices of religious norms», RELIGARE Working Paper, núm. 6, enero de 2011, pp. 2-3.

${ }^{71}$ Las reglas comerciales del Islam se aplican por el Derecho Internacional y son aceptadas como de uso común en muchos ordenamientos estatales. Véanse S. HABACHY, «Property, right, and contract in Muslim Law», Columbia Law Review, vol. 62, 1962, pp. 450-473, y M. Hashim Kamali, Islamic Commercial Law. An analysis of futures and options, Cambridge, Cambridge University Press, 2000. 
cobijo también a asuntos comerciales y financieros ${ }^{72}$ donde están implicados intereses económicos para los países que permiten la aplicación de un derecho religioso, y se debe hacer notar que en este campo ya no aparecen problemas de jurisdicción ni el debate sobre one law for all ${ }^{73}$. Los musulmanes hacen grandes inversiones en el país y muchas transacciones desde bancos islámicos, de ahí que la Ley de Arbitraje haya previsto que los acuerdos de los tribunales de arbitraje sean válidos aunque respondan a un derecho religioso como la Sharia ${ }^{74}$ y estén fuera de los términos propios del Derecho internacional, hasta el punto de que se dicta una ordenanza en la que se les incentiva indirectamente mediante excepciones fiscales, préstamos sin intereses y otras ventajas ${ }^{75}$.

El sumando religión es el que aporta un distintivo a una antigua forma de resolver controversias. Fernández de Buján ${ }^{76}$ nos descubre que, conforme a las referencias contenidas en textos jurídicos y literarios, parece razonable pensar que el arbitraje existía en los primeros tiempos de la comunidad política romana, con anterioridad a la organización de la administración de la justicia y de la atribución de competencias a magistrados y jueces; la decisión de controversias entre los particulares se encargaría a uno o varios árbitros elegidos de común acuerdo por los interesados en solucionar sus conflictos. En el Tratado Foedus Cassianum se contenían disposiciones reguladoras de los litigios surgidos entre miembros de las distintas comunidades, que se producirían especialmente en el marco de las relaciones comerciales. La conexión entre el Derecho latino y el anglosajón a través de la bona fides y la equidad hacen del arbitraje una institución jurídica en ambas culturas.

72 También en Estados Unidos se aplica el arbitraje para estos asuntos tras la mediación. Cfr. bttp://www.finra.org/ArbitrationAndMediation/FINRADisputeResolution/ (fecha de consulta: 11 de septiembre de 2013), y A. P. ORDOver y A. DONEFF, Alternatives to Litigation: Mediation, Arbitration, and the Art of Dispute Resolution, LexisNexis-National Institute for Trial Advocacy, USA, 2002.

${ }^{73}$ En el ámbito internacional también se firman acuerdos que establecen las reglas de arbitraje desde principios del siglo xx. Véase «Documents», The American Journal of International Law, vol. 57, 1963, pp. 500-511.

74 «The development of MAT will allow the resolution of disputes by recourse to religious principles thanks to the exemptions stated in the Arbitration Act» (Z. AKHATAR, «Conflict of laws, Sharia rules and dispute resolution», International Arbitration Law Review, vol. 14, núm. 2, 2011, p. 4).

${ }^{75}$ Financial Services and Markets Act 2000 (Regulated Activities) (Amendment) Order 2010.

76 A. FERNÁNDEZ DE BuJÁn, Derecho público romano. Recepción, jurisdicción y arbitraje, Madrid, Civitas, 2004, pp. 397-414. Véase también su trabajo «El arbitraje de Derecho público en la experiencia jurídica romana», El Cronista, núm. 37, 2013, pp. 48-61. 


\section{SHARIA COUNCILS Y MUSLIM ARBITRATION TRIBUNALS}

\section{Procedimiento de los Shariab Councils}

Aunque de modo informal, los councils ya existían desde los años setenta. Fue en la década de los ochenta cuando comenzaron a funcionar, especialmente en Londres y Birmingham, haciendo públicos sus procedimientos judiciales.

Los councils no se denominan a sí mismos como tribunales religiosos, pero en este trabajo, al igual que parte de la doctrina ${ }^{77}$, los consideraremos como tales para distinguirlos de los tribunales de arbitraje que ofrecen una resolución alternativa al conflicto.

Los tribunales religiosos islámicos tienen conexiones y diferencias con los tribunales eclesiásticos católicos y los judíos - Beth Din-. Con independencia de estos rasgos comunes y diferenciadores entre los tribunales de las tres religiones, todos deben su existencia al sentido de «pertenencia», de «identidad religiosa» que necesita «acomodación» a través de sus propias instituciones en una sociedad secular, y a esta idea se suma una parte minoritaria de la doctrina ${ }^{78}$.

Pues bien, el lugar común donde se agudiza el sentido de conciencia religiosa es el del matrimonio y la familia. Cuando los Sharia Councils deciden sobre cuestiones de familia pueden juzgar en torno al momento constitutivo o al extintivo. Los musulmanes tienen muy poco margen en lo que a la celebración del matrimonio respecta, aunque existe la posibilidad de contraer matrimonio religioso y matrimonio civil con eficacia en ambos órdenes. La celebración del matrimonio religioso para un creyente resulta una cuestión vital por razón de fe, pero las ventajas que proporciona el estatus matrimonial en la sociedad civil les invita a inscribirlo en el registro oficial según las formalidades previstas por la ley.

77 "We adopt the term "tribunal" to describe them all because we regard it as equivalent to "court", and use it in preference to the latter, both because the word "court" bas become loaded with connotations of coercive enforcement and also because two of the three religious institutions in our study do not in any event describe themselves as "courts". We use the term "court" or "tribunal" in the functional senses identified by Roger Cotterrell, as going beyond "dispute resolution" to embrace administrative processing and enforcement of norms through the application and development of legal doctrine» (G. Douglas, N. DoE, S. Gilliat-RaY, R. SANDBERg y A. KHAN, «The role of religious tribunals in regulating marriage and divorce», Child and Family Law Quarterly, vol. 24, núm. 2, 2012, p. 141).

${ }^{78}$ Ibid., p. 155. 
El conflicto se plantea cuando no se registra oficialmente el matrimonio religioso, conocido como nikah, de modo que no tiene efectos civiles. El nikah es un contrato privado que puede verse seguido de una boda civil, pero muchas parejas no llegan nunca a contraerlo, por lo que el matrimonio religioso no existe para el derecho secular pero sí tiene plena eficacia en el derecho religioso, y es sobre estos matrimonios sobre los que resuelve el tribunal musulmán, una vez que se ocasiona la ruptura del mismo.

Actualmente se califican meramente de non-marriages, pero en la Marriage Act 1949 un matrimonio sin licencia, que no sigue los usos de la sociedad de amigos, o de los judíos, celebrado fuera de un lugar de culto de la Iglesia de Inglaterra, o en un edificio oficial, de conformidad con la sección 75 podría ser constitutivo de delito ${ }^{79}$. A modo de ejemplo, en $R$ vs. Bham ${ }^{80}$ el apelante se enfrentó a una acusación bajo la sección citada por el hecho de haber celebrado como imán una ceremonia o nikak entre un varón musulmán y una adolescente de dieciséis años en una casa privada, aunque la niña se había convertido al Islam y contaba con el consentimiento de los padres. En lo que respecta al supuesto momento constitutivo, el tribunal dictaminó que no se había creado un válido estatus matrimonial.

$\mathrm{Al}$ contrario, si se cuestiona la validez de la ceremonia por un país islámico la decisión hubiera sido distinta, debido a la importancia que se le otorga al estatuto personal. Así, el Tribunal Supremo de Paquistán ${ }^{81}$ decidió que era válido un matrimonio celebrado entre un varón musulmán y una joven española en Londres debido al estatuto personal del esposo ${ }^{82}$.

Centrándonos en el momento extintivo, ante el conflicto de leyes, el Reino Unido opta por el test del domicilio, salvo que la decisión no sea equitativa, mientras que otros países optan por el estatuto personal, aun-

79 «75. Offences relating to solemnization of marriages. (2) Any person who knowingly and wilfully: (a) solemnizes a marriage (not being a marriage by special license, a marriage according to the usages of the Society of Friends or a marriage between two persons professing the Jewish religion according to the usages of the Jews) in any place other than: (i) a church or other building in which marriages may be solemnized according to the rites of the Church of England, or (ii) the registered building office, approved premises or person's residence specified as the place where the marriage was to be solemnized in the notices of marriage and certificates required under Part III of this Act; shall be guilty of felony and shall be liable to imprisonment for a term not exceeding five years».

80 (1989) AC 1155.

81 (1967) PLD Supreme Court 580.

82 «It is, therefore, correct to say that the marriage of the parties in this case solemnized before a Registrar in England, according to the procedure laid down in the Marriage Act 1949, conforming as it does to the above requirements, would be recognized as valid, under Muslim law» (ibid., p. 602). 
que la aplicación de un derecho religioso origine una situación injusta para una de las partes, ya hablemos de Paquistán, India, algunos Estados africanos, Asia, etc. En Jatoi vs. Jatoi ${ }^{83}$ un musulmán domiciliado en Paquistán que regentaba un negocio en Londres contrae matrimonio con una joven española católica en la oficina del registro sito en Londres. Tras un año de convivencia, el marido abandona a su mujer que estaba embarazada y regresa a Paquistán, donde toma a una segunda mujer, en esta ocasión una suiza convertida al Islam.

La primera esposa solicita una orden de sostenimiento económico para ella y su hijo que se emite y se envía a Paquistán, donde se hace ejecutable judicialmente, pero el varón nunca cumple con su obligación. La mujer viaja a Karachi para reclamar la implementación de la orden, pero el marido decide repudiarla conforme a las prescripciones de la Muslim Family Laws Ordinance 1961 (MFLO).

Pues bien, ante el conflicto de leyes, la justicia paquistaní elige el criterio del estatuto personal del varón y se aplica el Derecho musulmán, de conformidad con el cual, tras el divorcio, ya no existe obligación de sustento económico por parte del varón.

Quizá por este motivo los musulmanes tienen otro estatus legal en el Reino Unido que el de los judíos; aunque éstos no se rigen por su ley personal, sí se percibe una mayor acomodación a su identidad. Como ya hemos mencionado, deben divorciarse previamente en el ámbito religioso para disolver el matrimonio en el orden civil, con el fin de que puedan volver a contraer matrimonio civil y no traicionar su conciencia religiosa. Sin embargo, la ley británica no aplica la misma regla a los musulmanes, de ahí que se actúa en sentido contrario, y son los Sharia councils los que obligan a los esposos a presentar una prueba de que el procedimiento de divorcio civil está en marcha o ya se ha obtenido la disolución.

Tanto en un caso como en el otro, matrimonio religioso con efectos civiles o contrato privado religioso, existe la obligación imperativa de intentar la reconciliación y, lo más importante, los musulmanes se someten al derecho religioso. No se trata de un acuerdo pactado con mediación y con la intervención de un árbitro, sino de someterse a la autoridad de un tribunal que aplica un cuerpo normativo, algo que podemos considerar como la máxima expresión de la pertenencia a una religión y adhesión a una misma fe.

83 (1967) PLD Supreme Court 580. Véase, sobre este tema, D. PEARL, «Muslim marriages in English law», Cambridge Law Journal, vol. 39, núm. 1, 1972, pp. 136-137. 
También los tribunales eclesiásticos católicos procuran la reconciliación de los cónyuges y se aplica un principio o presunción a favor de la validez del matrimonio, que como tal es un sacramento, de modo que se debe probar la inexistencia del mismo o nulidad, existiendo casos excepciones de disolución.

Ahora bien, los tribunales musulmanes y judíos tienen entre manos un contrato, a pesar de sus ritos, y procuran el divorcio cuando se constata una irreparable o irremediable ruptura (irretrievable breakdown), de ahí que se asemeje más al Derecho inglés y a la tradición protestante. El procedimiento de disolución del matrimonio musulmán es distinto según lo solicite el esposo o la esposa.

En definitiva, los Sharia councils trabajan siempre en torno al momento extintivo, pero nunca podrían tomar decisiones referentes a la disolución de gananciales o la custodia de los hijos.

\section{A) Si el divorcio es instado por el varón ${ }^{84}$}

Debido a las responsabilidades que tiene el varón de mantener a su familia, el derecho al divorcio se otorga primariamente al esposo. Un musulmán que quiere divorciarse es requerido para una reunión de arbitraje, en compañía de los ascendientes de la pareja, con el fin de intentar una reconciliación.

Si el hombre está convencido de no poder tener armonía en su vida conyugal se puede divorciar verbalmente o por escrito. En ambos casos es recomendada la presencia de dos testigos en el momento en que pronuncia sus palabras.

Un hombre debería divorciarse: $a$ ) solamente una vez; $b$ ) en el periodo de tiempo en el que su mujer tenga la menstruación, y $c$ ) no se debe tener relaciones sexuales desde la última menstruación de la esposa.

Cuando el marido pronuncia el repudio o talaq la mujer debe respetar un tiempo conocido como iddat, en el que tiene que conservar su castidad. Se le permite estar en la misma casa, pero no pueden tener relaciones íntimas.

El hombre puede decidir volver a tomar a su mujer, ya sea verbal o físicamente, teniendo relaciones sexuales de nuevo, siendo conveniente que 2013).

${ }^{84}$ Cfr. http://www.islamic-sharia.org/talaq.html (fecha de consulta: 7 de noviembre de 
haya dos testigos de la reconciliación. En el caso de que no suceda y el repudio se haya pronunciado tres veces se consolida el divorcio definitivamente, la mujer tiene que abandonar su casa y no hay opción de volver a contraer matrimonio entre sí.

Llegados a este punto el council emite un certificado de divorcio firmado por el solicitante en presencia de dos testigos. Así las cosas, se exige al varón que pague la dote a la esposa tal y como se estipuló en el contrato inicial de matrimonio.

El council debe notificar el divorcio por talaq a la mujer mediante escrito y asegurarse de que le ha sido pagada la dote.

Los casos de divorcio sólo pueden ser conducidos por un council cuando se trate de un divorcio islámico y en el que el sistema legal o judicial del Reino Unido no tenga competencia. En el caso de pretenderse un divorcio civil, o solicitar asesoramiento sobre el mismo, se indica que debe acudirse a un representante legal cualificado.

\section{B) Si el divorcio es instado por la mujer ${ }^{85}$}

En estos procedimientos, mayoritariamente utilizados por mujeres, se suelen resolver casos de divorcio de matrimonios celebrados en otro país y por nikah, es decir, sin validez en tribunales seculares del Reino Unido.

Cuando la mujer inicia un procedimiento de divorcio — su voluntad «en femenino» se distancia del repudio unilateral del varón- podríamos afirmar que se está procediendo a un kbul, que contiene ciertas peculiaridades como la necesidad de entregar la parte de la dote que ya haya recibido para sufragar gastos y la renuncia posterior de toda la dote si el marido accede al divorcio.

Una vez presentada su solicitud, el council la requiere para una entrevista y luego se pone en contacto con el esposo para notificarle la petición. Tanto si el varón responde o no — se da un plazo de un mes si reside en el Reino Unido y de dos si reside en extranjero- el council tiene la obligación de elaborar un informe con las entrevistas mantenidas con ambos y de reunirse mensualmente hasta que se alcance una decisión por parte de los miembros del council, y finalmente se concede el divorcio solicitado por la mujer. de 2013).

${ }^{85}$ Cfr. http://www.islamic-sharia.org/kbula.html (fecha de consulta: 7 de noviembre 
Se exigen cuatro requisitos para conseguir el divorcio: 1) que se haya instado también el divorcio civil, ya que la Religious Marriages Act 2012 parece ir dirigida sólo a los judíos; 2) aportar la prueba de la separación de los esposos durante al menos un año, aunque algunos consejeros exigen un tiempo de dos años y, además, procuran la conciliación; 3) en el caso de custodia física por parte de la mujer, asegurar que el marido pueda ver a sus hijos; 4) sólo en determinados casos se reclama que el varón pague la dote establecida al inicio de la ceremonia mediante contrato.

Como hay distintos procedimientos a seguir se suele dar a elegir al cliente y se entrega un documento a modo de certificado que resulta legal en los países islámicos de origen.

\section{Composición y procedimiento del MAT}

Cuando un matrimonio musulmán se rompe puede ir a un tribunal que se rige por la Sharia, que asesora y guía en cuestiones de Derecho islámico y de moralidad, y también ofrece servicios de mediación intentando resolver conflictos civiles y de familia. Su asistencia es requerida generalmente por mujeres divorciadas, ya que sólo los hombres tienen legitimación para pronunciar el divorcio mediante la figura conocida como talaq o repudio.

Debido a que el matrimonio se califica como un puro contrato, también se puede disolver por incumplimiento del mismo. Un supuesto común es el de añadir una cláusula como la de prohibir al marido que practique la poligamia, de modo que si toma una segunda esposa la primera mujer puede solicitar el divorcio.

Los consejos también pueden extinguir un matrimonio por motivos fundamentados, como es la nulidad de un matrimonio por defecto en el contrato matrimonial: Falsk.

La jurisprudencia islámica conocida como fiqh tiene varias escuelas, entre las más conocidas están: Hanafi, Maliki, Shafii y Hanbali ${ }^{86}$. La jurisprudencia es la que aplica los preceptos divinos islámicos a la situación concreta, por lo que la escuela tiene un papel decisivo en la interpretación.

El tribunal o MAT está compuesto por personas que pueden aportar la sabiduría legal y la religiosa. Se trata de asesores legales con al menos

${ }^{86}$ L. A. Khan, «The immutability of Divine Texts», Brigham Young University Law Review, núm. 807, 2008, pp. 24-25. 
tres años de experiencia en el ejercicio de la profesión y expertos en Islam, valiosos por sus estudios y su experiencia ${ }^{87}$.

Los asesores deben cuidar de que los árbitros legales no olviden los principios legales islámicos, pero ambos deben estar conformes de modo unánime en la decisión que se tome.

Las garantías legales que deben ofrecer los acuerdos arbitrados obedecen a la necesidad de responder siempre al interés público. No obstante, no se debe intervenir salvo que esté previsto en la Ley de Arbitraje de 1996.

Las partes implicadas siempre pueden realizar una opción de ley, y una vez que elijan el derecho aplicable, ya sea de Inglaterra, Escocia o Gales, los acuerdos tendrán que ajustarse a los términos de tales normas ${ }^{88}$.

En orden a dar ejecución a los acuerdos arbitrados ${ }^{89}$, se debe alcanzar la certeza de que son válidos ${ }^{90}$ y que los árbitros no incurren en alguna causa de remoción de cargo por falta de imparcialidad, de cualificación, si incurre en alguna causa de incapacidad, por no conducir apropiadamente el proceso o de modo razonable, etc ${ }^{91}$.

$87 \ll c .23, \$ 10$ (1) The Tribunal shall consist of as a minimum a: Scholar of Islamic Sacred Law; Solicitor or Barrister of England and Wales». Cfr. Procedure Rules of the Muslim Arbitration Tribunal, bttp://www.matribunal.com/procedure_rules.html.

$88 \ll c .23$ \&46. Rules applicable to substance of dispute. (1) The arbitral tribunal shall decide the dispute: (a) in accordance with the law chosen by the parties as applicable to the substance of the dispute, or (b) if the parties so agree, in accordance with such other considerations as are agreed by them or determined by the tribunal. (2) For this purpose the choice of the laws of a country shall be understood to refer to the substantive laws of that country and not its conflict of laws rules. (3) If or to the extent that there is no such choice or agreement, the tribunal shall apply the law determined by the conflict of laws rules which it considers applicable». Cfr. ibid.

$89 \ll c .23, \$ 66$. Enforcement of the award. (1) An award made by the tribunal pursuant to an arbitration agreement may, by leave of the court, be enforced in the same manner as a judgment or order of the court to the same effect. (2) Where leave is so given, judgment may be entered in terms of the award. (3) Leave to enforce an award shall not be given where, or to the extent that, the person against whom it is sought to be enforced shows that the tribunal lacked substantive jurisdiction to make the award. The right to raise such an objection may have been lost (see section 73). (4) Nothing in this section affects the recognition or enforcement of an award under any other enactment or rule of law, in particular under Part II of the M1Arbitration Act 1950 (enforcement of awards under Geneva Convention) or the provisions of Part III of this Act relating to the recognition and enforcement of awards under the New York Convention or by an action on the award». Cfr. ibid.

$90 \ll c .23, \$ 9$. Stay of legal proceedings. (4) On an application under this section the court shall grant a stay unless satisfied that the arbitration agreement is null and void, inoperative, or incapable of being performed». Cfr. ibid.

${ }_{91}$ El Tribunal Supremo ha afirmado que no se les aplica la European Employment Equality (Religion and Belief) Regulations 2003, es decir, que no es causa de remoción la afiliación religiosa del árbitro [Hashwani vs. Hivraj (2011) UKSC 40]. Cfr. bttp://www.supre- 
La parte ${ }^{92}$ que se considere perdedora en esta decisión arbitrada tendrá la oportunidad de acudir a una revisión judicial en el ámbito civil ${ }^{93}$. También se puede modificar o confirmar el veredicto del MAT si una de las partes así lo demanda ${ }^{94}$.

Ahora bien, si ninguna de las partes actúa una pretensión para que el tribunal judicial intervenga, puede ocurrir que un veredicto no se enfrente frontalmente a conceptos legales seculares y que se le otorgue fuerza legal porque se adecua a los términos establecidos en la Ley de Arbitraje.

\section{Las enmiendas del one law for all en los acuerdos de arbitraje}

Así las cosas, la Ley de Arbitraje de 1996 sí permite resolver conflictos outside state courtroom y dentro de tribunales religiosos de arbitraje ${ }^{95}$. Los mismos tribunales seculares ceden paso al arbitraje, como en el caso Halpern vs. Halpern ${ }^{96}$. Además, aunque esta ley se ha convertido en el epicentro del terremoto, el arbitraje tiene ya una histórica y continuada progresión en la legislación inglesa: la primera ley fue promulgada en el año 1698, seguida de otras en 1889, 1934, 1950 y 1979, que pretendían limitar la intervención judicial.

En el año 2007 se crea el primer Tribunal de Arbitraje situado en Hijaz College Islamic University (Nuneaton, Reino Unido) ${ }^{97}$, que paulatinamente van aumentado como Informal Sharia Councils resolviendo disputas, especialmente en materia de familia.

mecourt.gov.uk/decided-cases/docs/UKSC_2010_0158_Judgment.pdf (fecha de consulta: 29 de octubre de 2013).

${ }_{92} \ll c .23$. Powers of the court in relation to award: $\$ 66$. Enforcement of the award: $\$ 67$. Challenging the award: substantive jurisdiction: $\$ 68$. Challenging the award: serious irregularity: $\$ 69$. Appeal on point of law: $\$ 70$. Challenge or appeal: supplementary provisions: $\$ 71$. Challenge or appeal: effect of order of court».

${ }_{93}$ Cfr. ibid.

94 Véase c. 23, $\$ 67$.

${ }^{95}$ Las decisiones arbitradas no se aplican únicamente en estos tres supuestos: «(1) Lack of substantive jurisdiction; (2) Serious irregularity; (3) Challenge to point of law» (Arbitration Act 1996, pp. 67-69).

96 (2007) EWCA Civ 291.

${ }_{97}$ «Although is a single tribunal, it can travel anywhere in the country to accommodate the parties» (M. RAFEEQ, «Rethinking Islamic Law Arbitration Tribunals: are they compatible with traditional American notions of justice?», Wisconsin International Law Journal, vol. 28, núm. 1, 2013, p. 124). 
Mientas Akhtar ${ }^{98}$ ofrece las ventajas de los MAT frente a los councils, otros autores centran su atención en las desventajas. Así, debido a que a menudo no es posible apelar el veredicto de un árbitro, salvo que todas las partes del proceso estén de acuerdo, Maret ${ }^{99}$ advierte que se crea un sistema legal paralelo:

«Therefore, under the Arbitration Act, English law has effectively created an outlet for parallel legal systems to acquire legitimacy».

Llegados a esta encrucijada, el Reino Unido juega con sus mejores cartas, las de sus compromisos europeos y, por tanto, la necesidad de reformar la legislación en materia de igualdad y no discriminación. A principios del siglo XXI se dictaron las directrices Equality Race Directives 2000 por el Consejo Europeo ${ }^{100}$, recomendando a los países integrantes que realizaran las respectivas reformas internas, lo que provocó la Ley de Igualdad inglesa Equality Act 2006. Esta ley no fue neutral, sino proactiva, puesto que obligó a las autoridades del sector público a eliminar toda discriminación y a promover la igualdad entre hombres y mujeres, para más tarde crear una comisión cuyas finalidades parecían mejor encauzadas al entendimiento de la diferencia y la diversidad dentro de una misma sociedad, la protección de los derechos individuales y la promoción del respeto entre los grupos. Me refiero a la Commision for Equality and Human Rights (CEHR).

Con el objetivo de simplificar estos cometidos y armonizar las medidas a tomar se dicta la Equality Act 2010 en su empeño por evitar la discriminación por razón de género, ausencia de libre consentimiento en materia de matrimonio y familia, etc. ${ }^{101}$ Sin embargo, sus medidas no son meramente preventivas, sino «correctivas», como vamos a comprobar más adelante, por lo que algunos han considerado que perjudica a las minorías religiosas y no aprecia las sensibilidades culturales de la población. A

${ }_{98}^{8}$ R. C. AкHTAR, «British Muslims and the evolution of the practice of Islamic Law with particular reference to dispute resolution», Journal of Islamic State Practices in International Law, vol. 6, núm. 1, 2010, pp. 31-32.

99 R. E. Maret, «Mind the gap: the equality bill and sharia arbitration in the United Kingdom», Boston Colleage International \& Comparative Law Review, vol. 36, núm. 1, 2013, p. 268.

${ }^{100}$ Council Directive 2000/43/EC, 29 de junio de 2000. Cfr. http://eur-lex.europa.eu/ (fecha de consulta: 8 de noviembre de 2013).

101 The Equality Act 2010 (Specific Duties) Regulations 2011. Cfr. En https://www.gov. uklequality-act-2010-guidance. 
esta ley sigue la Ley de Arbitraje y Servicios de Mediación, que entró en vigor en el año $2011^{102}$, aunque algunos de sus preceptos están en proceso de revisión ${ }^{103}$.

Siguiendo el ejemplo de Ontario, donde los intereses y valores públicos en una cuestión privada como el matrimonio ${ }^{104}$ abocaron en la prohibición absoluta de tomar decisiones de arbitraje sobre familia que no siguieran estrictamente las leyes de Ontario, después de diecisiete años de experiencia, el Reino Unido reconoce también el riesgo de los acuerdos de arbitraje sujetos a mandatos religiosos e introduce algunas enmiendas a la ley, además de aprobar algunas leyes en defensa de las mujeres, los niños y, en general, en favor de la igualdad y la no discriminación, pero no como un ataque a la religión, sino como medidas de prevención de posibles decisiones discriminatorias.

Me estoy refiriendo a la citada Ley de Arbitraje y Servicios de Mediación de 2011, no sin generar controversia en torno a los derechos en conflicto y a la limitación del ejercicio del derecho de libertad religiosa de aquellos que libremente quieren someterse a ciertas reglas.

La ley comienza invocando su propósito teleológico, como es el de ejercer cierta presión legal sobre los servicios de arbitraje y mediación en la implementación de la legislación sobre igualdad, en orden a proteger a las víctimas de violencia doméstica y abuso, y cualquier otra finalidad análoga.

Este objetivo originó varias enmiendas a: a) la Ley de Igualdad de 2010; b) la Ley de Arbitraje de 1996; c) la Ley de Derecho de Familia de 1996; d) la Ley de Orden Público y Justicia Criminal de 1994, y e) la Ley sobre el derecho de los tribunales y servicios legales de 1990.

${ }^{102}$ La ley es conocida en este texto como Arbitration and Mediation Services (Equality) Act 2011.

${ }_{103}$ Cfr. bttp://services.parliament.uk/bills/2013-14/arbitrationandmediationequalityservices.html.

104 "While I am in favor of the new legislation, both in the immediate context of family law protections and more broadly as a signal that we should be concerned about public interest values that get dealt with behind the veil of private arbitration, we need to be clear about what is, and what is not, at stake in this debate [...] This national and international interest has obviously stemmed from the fundamental gender, religious, and cultural questions at play in the debate» (T. C. W. FARROW, «Re-framing the Sharia Arbitration Debate», Constitutional Forum Constitutionnel, vol. 15, núm. 2, 2006, pp. 81-82). 


\section{A) The Equality Act $2010^{105}$}

En la previsión de servicios de mediación se enmiendan los siguientes aspectos: a) una persona no puede remunerar servicios de mediación o arbitraje que impliquen comisión de discriminación, persecución o abuso por razón de sexo; $b$ ) con el fin de evitar una acción judicial discriminatoria se prohíbe dar mayor peso a la prueba testifical de un hombre que al testimonio de una mujer; c) se consideran ilegales los procedimientos judiciales sobre herencia entre niños, ya sean hombres o mujeres, que no hagan una repartición imparcial y justa; $d$ ) también se prohíbe un juicio sobre herencia en el que los derechos de propiedad de las mujeres sean inferiores a los de los hombres ${ }^{106}$.

Esta enmienda va dirigida principalmente a evitar o corregir ciertas prácticas islámicas referentes a la herencia ${ }^{107}$. Se trataría de impedir que sólo pueda considerarse a personas pertenecientes a la misma religión como integrantes de la línea sucesoria. También se procura no perjudicar a las mujeres que han contraído matrimonio con varones no musulmanes con el fin de que no pierdan su herencia y a las niñas para que reciban la misma parte proporcional de la herencia que los menores varones, por el hecho de que éstos supuestamente vayan a traer el pan a casa o mantener la economía familiar ${ }^{108}$.

Las previsiones legales para eliminar las desventajas sufridas por las mujeres y los niños que se han descrito anteriormente se aplican también a aquellas personas que están casadas según sus tradiciones religiosas o están viviendo en poligamia. Estas medidas incluirían, entre otras cosas, la obli-

${ }_{105}$ Cfr. http://www.legislation.gov.uk/ukpga/2010/15/contents.

106 «a) A person cannot pay for mediation or arbitration services doing something that involves committing discrimination, harassment or abuse on the basis of sex; $b$ ) in order to prevent discrimination probibited action is considered to assess more evidence or the testimony of a man than a woman; c) procedures are illegal distribution of property and inberitance among children, whether male or women, not equitable, d) is also probibited inberitance procedure in which the property rights of women are lower than those of men».

107 Véase, sobre la herencia, I. K. PoOnAWALA, «Book of Inheritance», The Pillars of Islam, traducción de Asaf A. A. Fyzee, Oxford, Oxford University Press, 2004, pp. 360-397.

108 «a) Is inherited only between people of the same religion, and the woman was married to a non-Muslim husband never inherit your family or b) this inequality also affects children in the field of heritage, as the daughters receive only balf the inheritance, while males inherit whole, justifying that the children should take economic responsibilities in marriage and the family, while that women receive financial support after marriage» (R. E. MILLER, Muslim friends. Their faith and feeling. An introduction to Islam, Saint Louis, Concordia Pub House, 2008, p. 307). 
gación de informar a las personas que han obtenido reconocimiento oficial de su matrimonio de que la convivencia polígama es ilegal en el Reino Unido, como en la mayor parte de las sociedades occidentales.

\section{B) The Arbitration Act $1996^{109}$}

La Ley de Arbitraje de 1996 se enmienda con las mismas cuatro previsiones anteriormente citadas, añadiendo una quinta en la que se prohíbe la competencia en materia de arbitraje sobre decisiones de familia o de justicia criminal ${ }^{110}$.

\section{C) The Family Law Act $1996^{111}$}

Aunque la anterior previsión de la Arbitration Act 1996 parece anular toda posibilidad de decidir sobre materia de familia, lo cierto es que sí se toman tales acuerdos de arbitraje, pero sólo son válidos si obedecen a los requisitos básicos de las leyes seculares del Reino Unido, tal y como sucedió tras la abolición de la Ontario Arbitration Law 1991.

Todos estos acuerdos deben responder a una negociación previa basada en el consentimiento mutuo. La denuncia de la ausencia de consentimiento puede ser realizada por una de las partes, por un tercero o por cualquier otra persona con autorización judicial si se encuentra conexión con la causa, tiene conocimiento de las circunstancias y, por tanto, se considera razonable.

Para determinar si el consentimiento fue verdadero, el tribunal debe probar si las partes fueron debidamente informadas de sus derechos legales, incluyendo las alternativas como la mediación y cualquier otra negociación durante el proceso, y que ninguna de las partes ha sido manipulada o ha sufrido algún tipo de coacción psicológica, o fue persuadida a participar en el proceso de negociación en contra de su voluntad. Este procedimiento es lo que se conoce por «legal injunction» o «equitable remedy of mandatory injunction» ${ }^{112}$, porque actúa a posteriori de la decisión arbitrada a modo de revisión, corrección o remedio.

109 Cfr. http://www.legislation.gov.uk/ukpga/1996/23/contents.

110 «No question about family or criminal matters may be the subject of arbitration».

${ }_{111}$ Cfr. bttp://www.legislation.gov.uk/ukpga/1996/27/contents.

112 Véase, sobre el tema, R. Youngs, English, French, German Comparative Law, London, Routledge-Cavendish, 1998, p. 317. 
El pluralismo religioso es muy fuerte, pero parece improbable, aunque no imposible, que el Derecho inglés admita la aplicación del derecho religioso ${ }^{113}$, aunque sí es posible en el arbitraje con las correspondientes garantías legales ${ }^{114}$.

\section{D) The Criminal Justice and Public Order Act $1994^{115}$}

Esta ley fue enmendada en su sección sobre intimidación a las víctimas de abuso o violencia doméstica y establece también la prohibición de intimidación o coacción a testigos y miembros del jurado.

113 «Matrimonial Proceedings: Religion. Bridget Prentice: We do not issue any guidance on the validity of fatwas or other rulings by a religious authority because there is no need for such guidance. Shari' law has no jurisdiction in England and Wales and there is no intention to change this position. Similarly, we do not accommodate any other religious legal system in this country's laws. Any order in a family case is made or approved by a family judge applying English family law.

If, in a family dispute dealing with money or children, the parties to a judgment in a Shari' a council wish to have this recognized by English authorities, they are at liberty to draft a consent order embodying the terms of the agreement and submit it to an English court. This allows English judges to scrutinise it to ensure that it complies with English legal tenets.

The use of religious courts to deal with personal disputes is well established. Any member of a religious community has the option to use religious courts and to agree to abide by their decisions but these decisions are subject to national law and cannot be enforced through the national courts save in certain limited circumstances when the religious court acts as arbitrator within the meaning of the Arbitration Act 1996. Arbitration does not apply to family law and the only decisions which can be enforced are those relating to civil disputes.

Religious courts are always subservient to the established family courts of England and Wales» (House of Commons, 23 de octubre de 2008, column 560W). Cfr. http://www.publications.parliament.uk/pa/cm200708/cmbansrd/cm081023/text/81023w0020.htm (fecha de consulta: 29 de octubre de 2013).

114 «46. Rules applicable to substance of dispute. (1) The arbitral tribunal shall decide the dispute: (a) in accordance with the law chosen by the parties as applicable to the substance of the dispute, or (b) if the parties so agree, in accordance with such other considerations as are agreed by them or determined by the tribunal. (2) For this purpose the choice of the laws of a country shall be understood to refer to the substantive laws of that country and not its conflict of laws rules. (3) If or to the extent that there is no such choice or agreement, the tribunal shall apply the law determined by the conflict of laws rules which it considers applicable». Cfr. http://www.legislation.gov.uk/ukpga/1996/23/section/46 (fecha de consulta: 29 de octubre de 2013).

${ }_{115}$ Cfr. http://www.legislation.gov.uk/ukpga/1994/33/contents (fecha de consulta: 29 de octubre de 2013). 


\section{E) The Court and Legal Services Act 1990}

La ley de los tribunales sufre una enmienda que castiga a cualquier persona que sea operador de la justicia y tome decisiones injustas basadas en la falsedad de testimonios o de documentación, o si resuelve casos fuera de su jurisdicción o carece de competencia.

También se hace especial hincapié en que se considerará una actuación negligente aquella que no aplique las medidas de igualdad de género previstas en la Ley de 2010, una barricada difícil de derrumbar en el Islam ${ }^{116}$.

\section{PROPUESTA FINAL: LA ACOMODACIÓN ENTRE EL DERECHO RELIGIOSO Y EL DERECHO SECULAR}

\section{Gobernanza religiosa y acomodación}

Llegados a este punto se debe reconocer con Enright que esta situación ya antigua la han experimentado otras religiones para hacer efectivo su derecho:

«It may be that negotiating new problems around religious marriage will require us to draw on "sometbing old"»"117.

Si queremos seguir el término utilizado en el mundo anglosajón, «transformative accomodation», en el diccionario español de la RAE se dice, entre sus varias acepciones, que se refiere a: «Hacer que una cosa cambie o sea distinta, pero sin alterar sus características esenciales».

El sistema matrimonial facultativo anglosajón se identificaría con esta teoría que se conoce como «transformative accommodation» ${ }^{118}$, que permitiría una gobernanza conjunta (join governance) ${ }^{119}$. Se trataría de conceder al individuo la libertad de elección de la ley aplicable, al menos en la práctica.

116 B. MiLTON-EDWARDS, «Bringing down the barricade: the gender debate», en Islam $\mathcal{E}$ Politics in the contemporary world, Cambridge, Polity, 2004, pp. 118-148.

117 M. ENRIGHT, «Preferring the stranger? Towards an Irish approach to Muslim», Irish Jurist, vol. 49, 2013, p. 75.

118 S. Gilliat-Ray, N. Doe, R. SAndberg y A. Khan, «Accommodating Religious Divorce in the Secular State: a case study analysis», en M. MaclEan y J. EEKELAAR (eds.), Managing family justice in diverse societies, Oxford-Portland, Hart Publishing, 2013, p. 189.

119 Véase, sobre este tema, R. SAnberg, G. Douglas, N. Doe y S. Gilliat-RaY, «Britain's 
Como parte del discurso de la gobernanza, de la libertad religiosa y de la expresión de la propia identidad se muestra, entre otros ejemplos, el reconocimiento del divorcio religioso, aunque con un control exhaustivo a través de la creación de lo que se ha denominado Muslim Arbitration Tribunal (MAT) ${ }^{120}$ y según lo que se dispone en The Divorce Religious Marriages Act $2002^{121}$ sobre la necesidad de divorciarse según los usos religiosos antes de acudir a un tribunal estatal ${ }^{122}$. Fournier advierte que hay una dicotomía entre los críticos y los defensores del uso del derecho de familia religioso: los que adoptan una visión secular y consideran que el derecho religioso es una forma de opresión de la mujer, y los que toman la aplicación del derecho religioso como una forma de identidad, de modo que esta esfera privada y paralela de expresión normativa debería ser respetada como la propia de un Estado multicultural. Ahora bien, a su parecer ambas posiciones fallan al no percatarse de que las negociaciones en cuestiones de familia, especialmente de divorcio, son las que dan legitimidad a la aplicación del derecho religioso ${ }^{123}$ y es lo que probablemente ha impulsado la Ley de Arbitraje; el Estado sólo debe corregir la decisión alcanza-

Religious Tribunals: Joint Governance in Practice», Oxford Journal of Legal Studies, vol. 33 , núm. 2, 2013, pp. 263-292.

${ }^{120}$ En 2007 Shaykh Faiz Siddiqi estableció este Tribunal y publicó su punto de vista: "We believe in the co-existence of both English law and personal religious laws. We believe that the law of the land in which we live is binding upon each citizen, and we are not attempting to impose Shariah upon anyone. Shariah does however have its place in this society where it is our personal and religious law. What a great achievement it will be if we can produce a result to the satisfaction of both English and Islamic law!» (Values and equalities of MAT). Cfr. http://www.matribunal.comvalues.html (fecha de consulta: 10 de septiembre de 2013).

${ }^{121}$ «Power to refuse decree absolute if steps not taken to dissolve religious marriage (1) In the Matrimonial Causes Act 1973 (c. 18), insert: 10A Proceedings after decree nisi: religious marriage (1) This section applies if a decree of divorce has been granted but not made absolute and the parties to the marriage concerned: (a) were married in accordance with: (i) the usages of the Jews, or (ii) any other prescribed religious usages; and (b) must co-operate if the marriage is to be dissolved in accordance with those usages. (2) On the application of either party, the court may order that a decree of divorce is not to be made absolute until a declaration made by both parties that they have taken such steps as are required to dissolve the marriage in accordance with those usages is produced to the court» (The Divorce Religious Marriages Act 2002, cap. 27). Cfr. http://www.legislation.gov.uk/ukpga/2002/27/introduction.

${ }^{122}$ Esta ventaja se aplica a los judíos y a los cuáqueros, pero no se extiende también a los musulmanes, de ahí que Sandberg haga notar lo siguiente: «Nevertheless, the State law in this area is facilitative, if not sufficiently pluralistic» (R. SANDBERG, «Islam and English law», Law E Justice, vol. 164, 2010, p. 32).

${ }_{123}$ P. FouRnIER, «Calculating claims: Jewish and Muslim women navigating religion, economics and law in Canada», International Journal of Law in Context, vol. 8, núm. 1, 2012, p. 48. 
da tras la negociación que suponga un beneficio para el hombre y un alto coste para la mujer ${ }^{124}$.

No obstante, la interferencia del Estado a veces no se produce únicamente para corregir, sino para evitar automáticamente la aplicabilidad de normas religiosas cuando se tiene jurisdicción sobre la materia; por tanto, se puede evitar una decisión basada en principios discriminatorios ${ }^{125} \mathrm{O}$, por el contrario, llegar a instar un cierto totalitarismo estatal bajo la idea de que la administración de la justicia islámica es caprichosa y sin sentido de la equidad.

El problema es que de la moderada intervención se podría pasar a la invasiva, incluso sin previa petición, en casos considerados de extrema gravedad. Empero siempre existen riesgos. Recordemos cuando India estableció que las mujeres hindúes no recibieran la dote ni cuando sobreviniera su viudez ${ }^{126}$.

Pues bien, la acomodación que transforme el propio derecho ante la evidencia del pluralismo y de las demandas de libertad religiosa necesitaría una confrontación de ambas partes sobre lo negociable y lo no negociable:

a) Para una de las partes, algunas cuestiones pertenecen al corazón de la ortodoxia de la religión identificado como lo que entendemos generalmente por Derecho Divino. Topamos con la neutralidad estatal ante asuntos religiosos frente a la imposibilidad de las comunidades religiosas de prescindir de aquello que es una cuestión de identidad de la religión y de las personas que la profesan con la misma.

b) Para la otra parte, la lectura occidental de los derechos humanos no es objeto de pacto o transmutación. En lo que se refiere a la universalidad de los derechos humanos, el problema se centra en las distintas facciones islámicas existentes a lo largo y ancho del

${ }^{124}$ Ibid., p. 57.

125 Como en el caso Midani vs. Midani, en el que varias partes disputaban una herencia y, una vez tomada la decisión arbitrada por Sharia Council of London, suplicaron ante las autoridades estatales que no se concediera eficacia, puesto que no había existido acuerdo entre las partes y se basaba en principios discriminatorios. Véase Queen's Bench Division (Commercial Court) Al. Midani and another vs. Al. Midani and others (1999) 1 Lloyd's Rep. 923. Cfr. bttp://uniset.ca/other/cs6/19991LLR923.html (fecha de consulta: 6 de noviembre de 2013) y bttp://lexisweb.co.uk/cases/1999/february/al-midani-and-another-v-almidani-and-others (fecha de consulta: 6 de noviembre de 2013).

126 A. Malhotra y J. Malhotra, «Hindu Law and the Uniform Code», en B. Atkin y F. BANDA (eds.), The International Survey of Family Law, Bristol, Family Law, 2007, p. 107. 
mundo, algunas de las cuales viven en clara confrontación entre la interpretación del Derecho islámico y la sociedad moderna ${ }^{127}$.

En esta línea, McColgan ${ }^{128}$ argumenta con términos muy críticos que la religión no debe ser protegida ni de igual manera ni con un grado superior de cualidad al sexo, la orientación sexual, la raza y la discapacidad, porque la normativa de la Comunidad Europea no lo justifica y el intento de acomodación para algunas tendencias religiosas que perpetúan problemas de igualdad puede suponer una amenaza al régimen estatutario de no discriminación.

No obstante, además de la adhesión a la declaración de El Cairo ${ }^{129}$ en enero de 2008, alrededor de 400 musulmanes firmaron un carta de valores («Charter of Values») en Bruselas ante el presidente del Parlamento Europeo. Bajo el liderazgo de la federación llamada Federation of Islamic Organisations in Europe (FIOE) respaldaron la neutralidad estatal que respete la expresión multifacética del ejercicio de libertad religio$\mathrm{sa}^{130}$ y apoyaron el concepto de transformative accomodation, sosteniendo una visión pluralista en la que las diferencias se vean como enriquecimiento mutuo ${ }^{131}$.

${ }^{127}$ Véase una perspectiva del Islam y la sociedad en J. KREINATH (ed.), The anthropology of Islam reader, London-New York, Routledge, 2012.

128 A. McColgan, «Class Wars? Religion and Inequality in the workplace», Industrial Law Journal, vol. 38, núm. 1, 2008, p. 1.

129 Véase, sobre este tema, A. AL-Ahsan, «Law, Religion and Human Dignity in the Muslim world today: an examination of OIC's Cairo Declaration of Human Rights», Journal of Law E Religion, vol. 24, 2008-2009, pp. 569 y ss.

${ }_{130}$ «Muslims of Europe Charter. 18. Muslims of Europe adbere to the principle of neutrality of the state regarding religious affairs. This means dealing fairly with all religions and allows those who hold religious values to express their beliefs and practice the rites of their religion either as individuals or groups, inconformity with European and international human rights charters and treaties. Muslims have, therefore, the right, as religious communities, to establish mosques, religious, educational and welfare institutions, to practice their religion in day-to-day affairs such as diet, clothing and other needs». Cfr. En http://www.itstime.it/Approfondimenti/muslims_of_europe_charter.pdf (fecha de consulta: 12 de julio de 2013).

131 «22. Muslims of Europe emphasize their respect for pluralism and the religious and philosophical diversity of the multicultural societies they live in. They believe that Islam affirms the diversity and differences that exists between people and is not discomforted by this multicultural reality. Rather, Islam calls for members of society to appreciate and enrich one another through their differences». Cfr. ibid. 


\section{Los desafíos de la acomodación. Hacia una razonable transformación}

La acomodación transformadora o constructiva se enfrenta a varios desafíos:

1. ${ }^{\circ}$ El temor hacia el fundamentalismo, que puede centrarse en la imposibilidad de aplicar el Derecho criminal o penal de un derecho religioso.

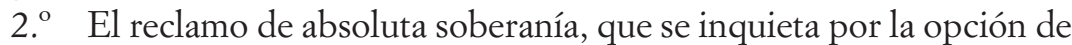
un régimen de concurrencia jurisdiccional.

En el Reino Unido, donde hay tribunales estatales, tribunales eclesiásticos cristianos (ya sea de la Iglesia de Inglaterra o la Iglesia Católica), tribunales rabínicos y tribunales islámicos, nos encontramos con jurisdicciones paralelas sin que el Estado se lo reconozca a sí mismo.

Dependiendo de la materia pueden ser jurisdicciones exclusivas o concurrentes, modelo en el que es único Israel ${ }^{132}$. No se podrá juzgar sobre un matrimonio religioso islámico, rabínico o católico romano porque pertenecen a jurisdicciones que reclaman su gobernanza teocrática, pero se les puede negar efectos civiles, tema en el que hasta los tribunales constitucionales se han convertido en guardianes de intereses seculares, incluso en países donde la religión es casi fundacional en la escala social y cultural ${ }^{133}$.

En algunos países, por el contrario, hay una remisión global a la norma religiosa, como en el Líbano. En la sentencia de la Rota Romana vs. Verginelli, de 17 de octubre de 2003, se aprecia todo el dilema entre el estatuto personal y la pluralidad de ordenamientos con otras implicaciones no de menor peso ${ }^{134}$.

132 D. HACKeR, «Religious Tribunals in democratic States...», op. cit., pp. 59-82. En Israel, al igual que en Líbano y en Palestina, también existen los «Druze Religious Courts». La comunidad de los drusos constituye una rama extrema del shiismo que tiene jurisdicción exclusiva en materia de familia. Véase, sobre este tema, A. LAYISH, «Islam as a source of law in the Druze religious Courts», Israel Law Review, vol. 14, 1979, pp. 13-30.

133 «The results have been an unprecedented judicialization of foundational collective identity, particularly in the realm of religion and state questions, and the consequent emergence of constitutional courts as important guardians of secular interests in these countries» (R. HIRSCHL, «Constitutional Courts vs. Religious Fundamentalism: Three Middle Eastern Tales», Texas Law Review, vol. 82, 2004, p. 1819).

${ }^{134}$ R. Rodríguez CHACÓN, «Estatuto personal y Rota Romana (una muy peculiar intervención del Tribunal de la Rota Romana sobre custodia de los hijos y fijación de pensión alimenticia con motivo del cambio de religión de un libanés)», Anuario de Derecho Eclesiástico del Estado, núm. 29, 2013, pp. 545-581. 
Hay ciertos asuntos que se pueden plantear ante los tribunales civiles y religiosos, aunque a veces se obliga a acudir antes a la jurisdicción civil. Y si no se establece este orden de prelación, los tribunales estatales siempre se reservan el derecho de revisión.

Fuera de este esquema, pero con las mismas prevenciones legales, están las decisiones tomadas mediante acuerdo de arbitraje consentido por las partes implicadas, que no siempre adquieren fuerza legal ante los tribunales civiles si no se ajustan al Derecho estatal.

En definitiva, aun sin admitir una justicia paralela en asuntos de familia, no conviene mantener el arbitraje religioso como una realidad no regulada porque despierta una situación de mayor alerta, como advierte Shachar:

«The vision of privatized diversity, in its full-fledged unregulated islands of jurisdiction variant, thus poses a challenge to the superiority of secular family law by its old adversary: religion» ${ }^{135}$.

3. La igualdad de derechos en materia de género que no entiende de tradiciones religiosas.

Sólo apuntar dos matices. Por una parte, no debemos olvidar que algunas normas británicas se basan en criterios teológicos como el de la unidad, que hace perder el apellido a la mujer cuando contrae matrimonio y asume el del marido, medida cuestionada como discriminación por razón de sexo de conformidad con las resoluciones del TEDH, como pudimos comprobar en Ünal Tekeli vs. Turkey ${ }^{136}$.

Por otra parte, en Europa algunos autores se cuestionan que la justicia islámica se acomode al Convenio Europeo de Derechos Humanos. Así, McGoldrick ${ }^{137}$ reclama el compromiso de adaptación de los musulmanes, más que la acomodación por parte de las legislaciones europeas de los Estados firmantes:

«The theme of this article has been to advocate an approach which begins with Muslim engagement with the Convention rather than one which begins with claims for the incorporation of Sharia law into its.

135 A. SHACHAR, «Privatizing diversity: a cautionary tale from religious arbitration in family Law», op. cit., p. 584.

136 (2005) 1 FCR 663. Véase 15 Human Rights. Case Digest 447 (2004-2005), pp. 447 y ss.

137 D. MCGOLDRICK, «Accommodating Muslims in Europe: from adopting Sharia Law to religiously based opt outs from generally applicable laws», Human Rights Law Review, vol. 9, 2009, p. 644. 
Mientras un sector de la doctrina especialista en Derecho matrimonial islámico sugiere que el legislador británico reevalúe el derecho de familia a la luz del mensaje pragmático de la Sharia dotado de profundos valores sociales ${ }^{138}$, la Ley de Arbitraje y Servicios de Mediación de 2011 en el Reino Unido ha sido también una continuación de la línea canadiense ${ }^{139}$, debido a que incluso las mujeres musulmanas expertas en Derecho islámico, como Bano ${ }^{140}$, sugieren que los tribunales religiosos crean limitaciones para las mujeres:

«Religious arbitration bodies may provide spaces for new forms of governance to resolve marital disputes away from the context of a Western secular framework, but this does not imply that these local settings predetermine a more suitable outcome for the parties involved. For example, religious and socio-cultural terms of reference often marginalize women».

En realidad, género y religión son dos componentes altamente inflamables en el ambiente político que impiden la privatización de la diversidad religiosa ${ }^{141}$. Como afirma Jänterä-Jareborg ${ }^{142}$ : «In many European societies, religion is regarded as a dark force conserving inequalities».

$4 .^{\circ} \quad$ El riesgo de la pérdida de poder coercitivo que abre el surco profundo trazado por los objetores de conciencia.

En este punto conviene traer a colación las declaraciones del arzobispo de Canterbury, que causaron gran impacto social y político, y de las cuales Jackson observó lo siguiente:

«It was a sophisticated, academically well-documented study, which analyzed some problems of multiculturalism in terms of political and legal

138 J. ReHman, «The Sharia, Islamic Family Laws, and International Human rights: examining the theory and practice of polygamy and talaq», International Journal of Law, Policy and the Family, vol. 21, 2008, p. 124.

${ }_{139}$ El gobierno de Ontario aprobó una ley (Family Statute Law Amendment Act 2006) la cual enmendó The Arbitration Act 1991 y fue implementada por otra ley (Family Arbitration Act 2007) con el fin de evitar un sistema de arbitraje que fuera en detrimento de las personas más vulnerables.

${ }^{140}$ S. BANO, «In Pursuit of Religious and Legal Diversity: A Response to the Archbishop of Canterbury and the "Sharia Debate" in Britain», Ecclesiastical Law Journal, vol. 10, núm. 3, 2008, p. 307.

${ }^{141}$ Véase esta idea en A. SHACHAR, «Privatizing diversity: a cautionary tale from religious arbitration in family Law», Theoretical Inquiries in Law, vol. 9, 2008, p. 580.

${ }_{142}$ M. JÄNTERÄ-JAREBORG, «Cross-border family cases and religious diversity. What can judges do?», Project: Religious Diversity and Secular Models. Innovative approaches to Law and Policy, Working paper núm. 10, enero de 2013, p. 4. 
philosophy, it made no proposals, and insofar as it discussed the possibility of greater accommodation with Sharia law, it stressed the criteria for and limitations to be imposed on any such approach ${ }^{143}$.

El arzobispo, sin realizar un análisis jurídico de la situación, abogó por la inevitable aplicación del derecho de Sharia, aunque obviando cualquier referencia al régimen de jurisdicción aplicable en estos casos, pero coloca una piedra con la que tropieza la seguridad jurídica que ofrece la aplicación de un Derecho único para todos, especialmente en disputas maritales.

Su intervención parece dirigida a crear una especie de coalición religiosa liderada por la Iglesia de Inglaterra en favor de las exenciones por razones de conciencia religiosa, lo que denota la aplicación de la equidad, al menos moral, además de ser un estrategia política, ya que la acomodación consistiría en reconocer legalmente algunos casos de objeción de conciencia, no de modificar el Derecho secular. Así las cosas, se advierte de los riesgos de la aplicación del one law ${ }^{144}$, y a mí no me parece contemplar un intento de acomodación transformadora en el arzobispo Williams, sino de acomodación razonable.

Además, y en pro de esta posición que mantengo, ante la confrontación sobre la «permisible and impermisible accommodation» ${ }^{145}$, el arzobispo Williams alude a una razonable acomodación de la conciencia de los creyentes, quienes no quieren participar en los procesos en los que se aplica lo dispuesto por otro Derecho religioso:

«Williams takes is to recommend the accommodation of those believers who wish to exercise the liberty of conscientious opting-out from collaboration in procedures or practices that are in tension with the demands of particular religious groups» ${ }^{146}$.

143 B. JACKSON, «Transformative accommodation and religious law», Ecclesiastical Law Journal, vol. 11, núm. 2, 2009, p. 132.

144 Basándose en Levítico 24:22: «Del mismo modo juzgarás al forastero y al nativo, porque yo soy Yahveh vuestro Dios».

${ }_{145}$ «Permissible accommodations to religious practice are typically seen as other than support or endorsement. But some attempted accommodations cross over the line. They support and endorse religion and constitute forbidden establishments. The determination of when accommodations involve impermissible support and endorsement is one of the most complicated problems in the law of the religion clauses» (K. GREENAWALT, Religion and the Constitution. Free Exercise and Fairness, Princeton, Princeton University Press, 2006, p 442).

146 R. Williams, Civil and Religious Law in England: a religious perspective. Archbishop of Canterbury, op. cit., apéndice I (19). 